PONTIFÍCIA UNIVERSIDADE CATÓLICA DO RIO DE JANEIRO

\title{
Mulheres e líderes empreendedoras Estudo de Caso da Lídera
}

Graziela Costa Urdan

TRABALHO DE CONCLUSÃO DE CURSO

CENTRO DE CIÊNCIAS SOCIAIS DEPARTAMENTO DE ADMINISTRAÇÃO

Graduação em Administração de Empresas 


\section{Graziela Costa Urdan}

\section{Mulheres e líderes empreendedoras Estudo de Caso da Lídera}

Trabalho de Conclusão de Curso

Trabalho de Conclusão de Curso, apresentado ao programa de graduação em Administração da PUC-Rio como requisito parcial para a obtenção do título de graduação em Administração.

Orientador(a) :Lygia Alessandra Magalhães Magacho

Rio de Janeiro, novembro de 2018. 


\section{Agradecimentos}

Gostaria de agradecer a todas as pessoas que de alguma forma me ajudaram nesta trajetória e no desenvolvimento da minha monografia. Primeiramente, agradeço a Deus por ter me dado força para conseguir concluir este trabalho À minha família e especial aos meus pais, que me deram todo apoio emocional e palavras de força durante todo o processo.

À professora Lygia Magacho, minha orientadora, que foi fundamental com todas as orientações, por ter me introduziu à Lídera, por todo apoio oferecido a mim e por ter acreditado nesse trabalho até o fim do processo.

Às associadas e gestoras da Lídera pela contribuição da pesquisa de campo. 


\title{
Resumo
}

Urdan, Graziela. Mulheres e Líderes Empreendedoras - Estudo de Caso Lídera. 79 p. Trabalho de Conclusão de Curso - Departamento de Administração. Pontifícia Universidade Católica do Rio de Janeiro.

O empreendedorismo feminino vem ganhando destaque na cidade de Passo Fundo no Rio Grande do Sul, e diante dos desafios que as mulheres e líderes empreendedoras enfrentam foi identificada a necessidade de uma rede de apoio a mulheres que desejam empreender. Sendo assim, um grupo de mulheres se juntaram e formaram a Associação Lídera para fomentar e respaldar os empreendimentos femininos. Este trabalho tem como objetivo identificar as características empreendedoras das mulheres que se associaram a Lídera, os motivos para fazerem parte do grupo de acordo com os três pilares da entidade e o papel e modelo de liderança dessas mulheres.

Palavras-chave:

Empreendedorismo Feminino, Perfil Empreendedor Feminino, Liderança Feminina

\begin{abstract}
Urdan, Graziela. Women and Entrepreneurial Leaders - Case Study of Lídera. Rio de Janeiro, 2018. 79 p. Trabalho de Conclusão de Curso - Departamento de Administração. Pontifícia Universidade Católica do Rio de Janeiro.

Women entrepreneurship has been gaining prominence in the city of Passo Fundo in Rio Grande do Sul, and with this, the lack of a support network for women who wish to undertake has been identified. Thus, a group of women joined and formed the Lídera Association to foster and support women's entrepreneurship. The objective of this study is to identify the entrepreneurial characteristics of the women who were associated with Lídera, the reasons for being part of the group according to the three pillars of the entity and the role and leadership model of these women.
\end{abstract}

Keywords:

Female entrepreneurship, Female entrepreneur profile, Female Leadership. 


\section{Sumário}

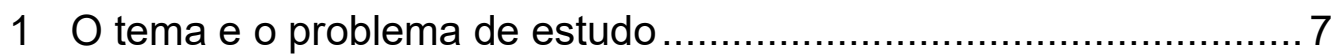

1.1. Introdução ao tema e ao problema do estudo .........................................

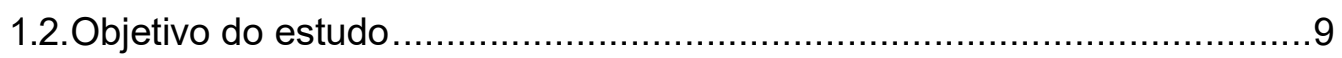

1.3. Objetivos intermediários do estudo............................................

1.4.Delimitação e foco do estudo............................................................10

1.5.Justificativa e relevância do estudo ...................................................10

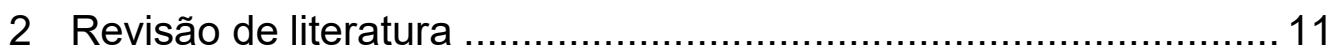

2.1.Empreendedorismo e Perfil empreendedor no Brasil e no Rio Grande do Sul 11

2.1.1 Empreendedorismo Feminino e Desafios................................ 20

2.2.Perfil Empreendedor Feminino ....................................................24

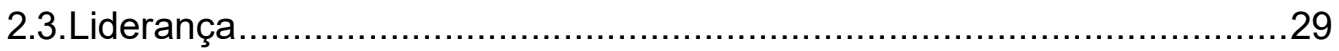

2.3.1 Liderança Feminina............................................................. 34

3 Métodos e procedimentos de coleta e de análise de dados do estudo ................................................................................... 37

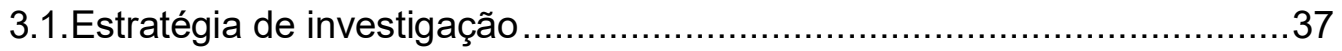

3.2.Procedimentos e instrumentos de coleta de dados ...............................37

3.3.Formas de tratamento e análise dos dados coletados ...........................38

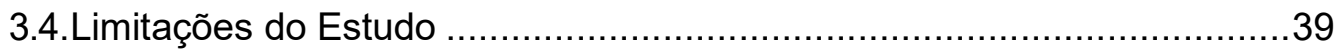

4 . Apresentação e análise dos resultados......................................40

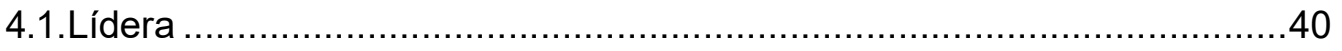

4.1.1 Idade e Nível de Escolaridade............................................... 41

4.2. Motivos das Associadas para Empreenderem .....................................45

4.2.1 Elaboração do Plano de Negócio ............................................ 46

4.2.2 Fonte de recursos utilizada pelas Associadas para abertura do negócio 47

4.2.3 Características dos negócios empreendidos pelas associadas à Lídera 48

4.2.4 Dificuldades enfrentadas pelas empreendedoras da Lídera ao abrirem o negócio

4.2.5 Rede de apoio e temas relevante para o empreendimento pela visão das Associadas.

4.2.6 Percepção das Associadas sobre faturamento pessoal e 
participação da renda no orçamento familiar .......................................... 52

4.2.7 Características Empreendedoras pelas entrevistadas................ 54

4.2.8 Percepção sobre Liderança pelas empreendedoras da Lídera..... 56

4.2.9 Rede de apoio e motivo por se associarem à Lídera................... 57

5 Conclusões e recomendações para novos estudos ..................... 61

6 Referências Bibliográficas .................................................. 63

Anexo I - Formulário .............................................................. 70

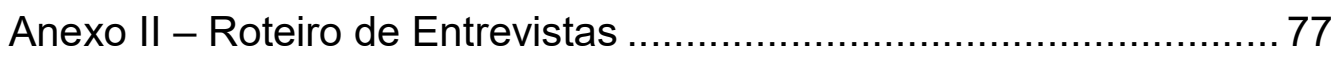




\section{O tema e o problema de estudo}

\subsection{Introdução ao tema e ao problema do estudo}

A inserção feminina no ambiente do empreendedorismo vem ganhando força nos últimos anos. Perante a atual conjuntura econômica do país, muitas mulheres estão buscando empreender diante de uma necessidade ou por enxergarem uma dor em determinado setor no mercado. Muitas encontram no empreendedorismo uma oportunidade para alcançar ou alavancar uma renda, alternativa de trabalho, desenvolvimento pessoal, realização profissional e maior flexibilidade de horário.

Segundo Raposo e Astoni (2007), o empreendedorismo do gênero feminino se configura como importante iniciativa da classe na busca por seus direitos de independência. $O$ crescimento da participação feminina no mercado de trabalho tem se refletido no empreendedorismo, onde as mulheres já correspondem a 51\% dos empreendedores iniciais, (GEM, 2017).

O Relatório Global de Empreendedorismo (Global Entrepreneurship Monitor - GEM) apresenta a distribuição percentual dos empreendedores por gênero conforme a Gráfico 1 (Gráfico 1.3 do GEM, 2017), considerando empreendimentos nascentes e empreendimentos já estabelecidos no mercado. É possível perceber claramente que as mulheres brasileiras são capazes de criar novos negócios na mesma dimensão que os homens (14,2 mi), porém ainda não possui um equilibro entre os gêneros no universo de empreendimentos estabelecidos (9,9 mi). 


\section{Gráfico 1: Taxas (em \%) (em milhões) do número de empreendedores por} gêneros segundo estágios do empreendimento - Brasil - 2017

Gráfico 1.3 - Taxas (em \%) específicas ${ }^{1}$ e estimativas ${ }^{2}$ (em milhões) do número de empreendedores por gêneros segundo estágios do empreendimento - Brasil - 2017

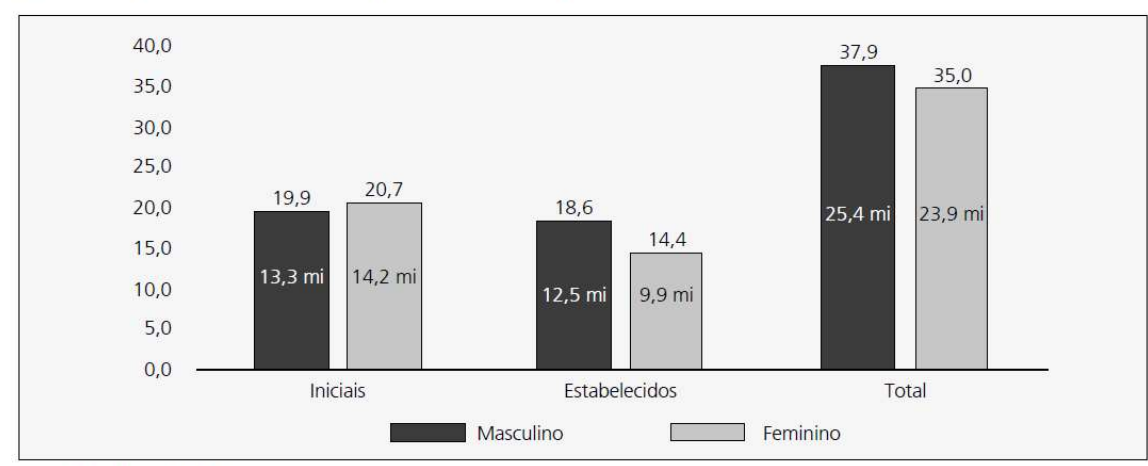

Fonte: GEM Brasil 2017

Percentual da população referente a cada categoria da população (ex. 19,9\% dos homens no Brasil são empreendedores iniciais).

2 Estimativa calculadas apartir de dados da população brasileira de 18 a 64 anos para o Brasil em 2017:135,4 milhões.Fonte: IBGE/Dire-

toria de Pesquisas. Projeção da população do Brasil e Unidades da Federação por sexo e idade para o período 2000-2030 (ano 2017).

Tal fenômeno pode estar associado às condições relatadas pelas empreendedoras brasileiras tais como: preconceito de gênero; menor credibilidade pelo fato de o mundo dos negócios ser mais tradicionalmente associado a homens; maior dificuldade de financiamento; e dificuldade para conciliar demandas da família e do empreendimento, (GEM, 2017).

A Organização para a Cooperação e Desenvolvimento Econômico (OCDE 2016), realizou um relatório que revela que os investidores estão $60 \%$ mais propensos a investir em negócios liderados por homens do que por mulheres.

Porém, quando o assunto é liderança feminina, a pesquisa feita pela consultoria McKinsey por meio do estudo "Delivering Through Diversity" em fevereiro de 2018, aponta que a chance de uma empresa ter seu desempenho acima da média é de $21 \%$ maior quando são chefiadas por mulheres.

Vale ressaltar que, além da oportunidade de alavancar a renda familiar, a realidade brasileira é de que a mulher em muitos casos é quem sustenta a família. Segundo a Pesquisa Nacional por Amostra de Domicílios (PNAD, 2016), quatro em cada dez lares brasileiros são chefiados por mulheres, e, dessas, $41 \%$ são donas de negócios próprios.

As mulheres encontram mais obstáculos durante a trajetória para fazer seus negócios progredirem, e em função disso, o Brasil possui várias redes que asseguram e incentivam o empreendedorismo feminino. Os programas dessas redes promovem o empoderamento feminino no cenário empreendedor e também se dedicam a estruturar e orientar essas mulheres, não só na gestão e expansão de seus negócios, mas principalmente de maneira psicológica ou financeira. 
A partir do momento que a mulher se fortalece financeiramente ela se torna um reflexo positivo, transformando a realidade de sua família como também as comunidades onde vivem. No Rio Grande do Sul, especificamente na cidade de Passo Fundo, um grupo de mulheres empreendedoras identificaram a necessidade de uma entidade social que promovesse parcerias, negócios e ações em prol do desenvolvimento da cultura do empreendedorismo e da liderança feminina. Portanto, criaram a Lídera para atender aos anseios da mulher empreendedora por meio da promoção de workshops, networking, cursos e eventos, formatados para disseminar a cultura da liderança entre as mulheres.

Compreendendo a importância e relevância do tema empreendedorismo feminino e, principalmente, o impacto gerado na sociedade este estudo busca compreender os desafios dessas mulheres líderes e empreendedoras, e para tanto, enfocou o grupo de mulheres que criou a Lídera, uma espécie de confraria que fomenta o empreendedorismo, fortalece negócios e contribuí para o desenvolvimento profissional e pessoal de suas associadas.

\subsection{Objetivo do estudo}

O presente trabalho tem como objetivo principal identificar o perfil empreendedor feminino e suas características, em específico as mulheres que se associam à Lídera.

\subsection{Objetivos intermediários do estudo}

- Buscar referências nos principais autores que abordam o tema empreendedorismo feminino e liderança feminina.

- Identificar o perfil empreendedor feminino das mulheres associadas da Lídera;

- Compreender a percepção das mulheres da Lídera sobre a própria liderança;

- Identificar os principais desafios enfrentados pelas empreendedoras para a criação e o desenvolvimento dos negócios;

- $\quad$ Analisar os principais motivos pelo quais as mulheres buscam a Lídera;

- Compreender a relação entre liderança feminina e o empreendedorismo feminino;

- Analisar a participação das mulheres na renda da família após tornarem 
empreendedoras;

\subsection{Delimitação e foco do estudo}

Este estudo tem como foco especificamente o perfil empreendedor feminino das associadas da Lídera, e como a associação contribui para o crescimento e fortalecimento dos empreendimentos e apoia as mulheres empreendedoras.

É importante também nesse estudo identificar as características de liderança feminina e os desafios enfrentados pelas mulheres que integram a Lídera, localizada na região de Passo Fundo no Rio Grande do Sul.

Embora relevante, não se pretende tratar da questão da liderança feminina empreendedora em todo território da cidade de Passo Fundo, e tão pouco analisar seus impactos socioeconômicos.

O estudo não pretende abordar profundamente quais os negócios e o nível de sucesso das empreendedoras estudadas $\mathrm{e}$ as trajetórias empreendedoras das mulheres associadas, assim como não pretende avaliar os resultados da Lídera.

\subsection{Justificativa e relevância do estudo}

As informações que esse estudo produziu podem se mostrar de interesse para o empoderamento feminino, fazendo com que as mulheres reconheçam que são capazes de empreender, e que se sintam fortalecidas a buscarem a equidade social e econômica. Os resultados alcançados também poderão ser úteis para estimular o empreendedorismo feminino de outras regiões do país.

Os conceitos e teorias estudadas podem servir de espelho para a criação de novas associações como a Lídera envolvendo a população de outras regiões do país, e a instigar as mulheres a liderarem e a empreenderem através da identificação das oportunidades do mercado.

Além disso, os resultados a serem alcançados ainda poderão ser úteis para pesquisadores sobre o tema, estudantes, publicações do meio acadêmico e para as futuras empreendedoras.

O trabalho também poderá ser utilizado pela própria Lídera, a fim de verificar se o modelo de serviços e suportes oferecidos atualmente, estão sendo eficientes e se existem oportunidades de criação de novos programas que atendam as demandas das associadas. 


\section{Revisão de literatura}

\subsection{Empreendedorismo e Perfil empreendedor no Brasil e no Rio Grande do Sul}

Segundo o economista Joseph A. Schumpeter, "o empreendedor é o agente de processo de destruição criativa que é o impulso fundamental que aciona e mantém em marcha o motor capitalista" (SCHUMPETER apud DEGEN, 2009, p. 1).

O mesmo autor conceitua que o empreendedor é responsável pela realização de novas combinações. Essas combinações podem ser identificadas por: introdução de um novo bem ou de uma nova qualidade de bem; introdução de um novo método de produção ou comercialização de um bem; abertura de novos mercados; conquista de novas fontes de oferta de matérias-primas ou de bens semi-faturados; e estabelecimentos de uma nova organização de qualquer indústria, abrangendo, assim, as coisas novas e as novas maneiras de se fazer.

O espírito empreendedor não é simplesmente ter coragem ou disposição para estabelecer um negócio. Está diretamente ligado à inovação a serviço do crescimento, à exploração de uma parcela de mercado imperceptível para muitos. É por meio desse ciclo renovável que impulsiona a capacidade de expansão da economia. Segundo Schumpeter (1949), o empreendedor é um indivíduo que destrói a ordem econômica pré-estabelecida para introduzir novos produtos e serviços, criando novas formas de organização ou explorando novos recursos e materiais.

"Um empreendedor é aquele que estará disposto a carregar o risco de um novo negócio se acreditar que há uma possibilidade significativa para se obter lucro". (SWOBODA apud PAULA, 2005, p.22).

Para Hisrch e Peters (2004), o empreendedorismo é o processo dinâmico de criar mais riqueza. A riqueza é criada por indivíduos, que assumem os principais riscos, em termos de patrimônio, comprometimento e tempo com a carreira. É o processo de criar algo novo com valor dedicando o esforço e o tempo necessários, assumindo riscos sociais, psíquicos e financeiros correspondentes e recebendo as recompensas consequentes da independência e satisfação econômica e pessoal.

Essa definição de empreendedorismo ressalta quatro vertentes básicas de ser um empreendedor, independente da área de atuação. Primeiro, que o 
empreendedorismo envolve o processo de criação, inovação. Segundo, exige a dedicação de tempo e de esforço necessário. Em sequência, assume os riscos indispensáveis. E por final, envolve as recompensas de ser um empreendedor, que é a independência, seguida de satisfação pessoal. Para alguns, o dinheiro é apenas o indicador do grau de sucesso $(\mathrm{HISRCH}$ e PETERS, 2004).

Empreendedorismo é o envolvimento de pessoas e processos que em conjunto levam a transformação de ideias em práticas e oportunidades. E a eficácia da implementação destas oportunidades leva a criação de negócios e ao sucesso (DORNELAS, 2008).

O empreendedorismo é viabilizado através das características do empreendedor sobre a percepção de oportunidade que possui cinco elementos: a criatividade e inovação, habilidade ao aplicar esta criatividade, força de vontade e fé, foco na geração de valor e correr riscos (WEVER; BRITTO, 2003).

Para Dornelas (2012), o empreendedorismo é o principal fator de desenvolvimento de um país, e o principal agente é o empreendedor, que consegue eliminar barreiras comerciais e culturais, diminuindo distâncias, possibilitando globalizar e renovar os conceitos econômicos, criando, assim, novas relações de trabalho e empregos, quebrando paradigmas e gerando riquezas para a sociedade.

Empreendedores são pessoas que perseguem o benefício, trabalham individual e coletivamente. São definidos como indivíduos que inovam, identificam e criam oportunidades de negócios, montam e coordenam novas combinações de recursos (MORI, 1998).

Segundo o GEM (2017); que tradicionalmente elabora um agrupamento das taxas; uma delas diz respeito às taxas de empreendedorismo segundo motivação do empreendedor, ou seja, que fatores o levaram a se envolver com atividades empreendedoras. Neste caso as taxas se dividem em empreendedorismo por oportunidade e por necessidade, conforme a Tabela 1. 
Tabela 1: Motivação dos empreendedores iniciais no Brasil

\begin{tabular}{lccc}
\hline Motivaçăo & Taxas & Percentual da TEA & Estimativas \\
\hline Oportunidade & 12,1 & 59,4 & 16.313 .253 \\
Necessidade & 8,1 & 39,9 & 10.965 .755 \\
Razåo Oportunidade/ Necessidade & & 1,5 & \\
\hline
\end{tabular}

\section{Fonte: GEM Brasil 2017}

' Percentual da populaçåo de 18 a 64 anos.

2 Proporçáo sobre a TEA: A soma dos valores pode náo totalizar 100\% quando houverem recusas elou respostas ausentes.

'Estimativas calculadas a partir de dados da populaçăo de 18 a 64 anos para o Brasil em 2017: 135,4 milhóes. Fonte: IBGE/Diretoria

de Pesquisas. Projeçào da populaçăo do Brasil e Unidades da Federaçăo por sexo e idade para o periodo $2000-2030$ (ano 2017).

Fonte: GEM, 2017.

No Rio Grande do Sul o emprendedorismo por oportunidade ocorre mais do que por necessidade. Segundo dados do (GEM-RS, 2016), as Taxas de Empreendedorismo por necessidade e por oportunidade no estado alcançaram $4,1 \%$ e $8,2 \%$, respectivamente.

A razão entre os empreendimentos por oportunidade e os empreendimentos por necessidade indica que, no estado do Rio Grande do Sul, para cada empreendimento criado por necessidade foram estruturados dois negócios por oportunidade. No Brasil essa razão se restringiu a 1,4.

A Tabela 2 apresenta as Taxas de Empreendedorismo por Necessidade e por Oportunidade no estado do Rio Grande do Sul.

Tabela 2: Motivação dos empreendedores Iniciais no Rio Grande do Sul - 2016.

\begin{tabular}{|c|c|c|c|}
\hline Motivação & Taxas & $\begin{array}{l}\text { Percentual } \\
\text { da TEA }\end{array}$ & $\begin{array}{c}\text { Número de } \\
\text { Empreendedores }\end{array}$ \\
\hline Oportunidade & 8,2 & 66,7 & 612.753 \\
\hline Necessidade & 4,1 & 33,3 & 305.967 \\
\hline Razão Oportunidade/Necessidade & & 2,0 & \\
\hline
\end{tabular}

Fonte: GEM Rio Grande do Sul 2016

'Percentual da população de 18 a 64 anos.

${ }^{2}$ Proporção sobre a TEA: A soma dos valores pode não totalizar $100 \%$ quando houverem recusas e/ou respostas ausentes.

${ }^{3}$ Estimativas calculadas a partir de dados da população de 18 a 64 anos para o Estado do Rio Grande do Sul em 2016:29,8 milhões. Fonte:

IBGE/Diretoria de Pesquisas. Projeção da população do Brasil e Unidades da Federação por sexo e idade para o período 2000-2030 (ano 2016 ).

Fonte: GEM RS 2016.

O Gráfico 2 a seguir apresenta as Taxas de Empreendedorismo segundo o grau de escolaridade no estado do Rio Grande do Sul.

É elevada a proporção dos empreendedores iniciais gaúchos $38,8 \%$ com "nenhuma educação formal ou ensino fundamental incompleto" no total desses empreendedores existentes no estado. No caso dos empreendedores estabelecidos essa proporção é maior $40,6 \%$-. Esse perfil indica para os órgãos de fomento a importância de políticas de educação e capacitação de parcela expressiva dos empreendedores gaúchos. No que se refere ao nível 
de escolaridade equivalente ao "superior completo, especialização incompleta e completa, mestrado incompleto e completo, doutorado incompleto e doutorado completo", esses percentuais são expressivamente inferiores: 7,3\% para os iniciais e 10,0\% entre os estabelecidos. (GEM-RS 2016).

Gráfico 2: Distribuição percentual dos empreendedores iniciais (TEA) e estabelecidos (TEE) segundo nível de escolaridade1 - Rio Grande do Sul - 2016

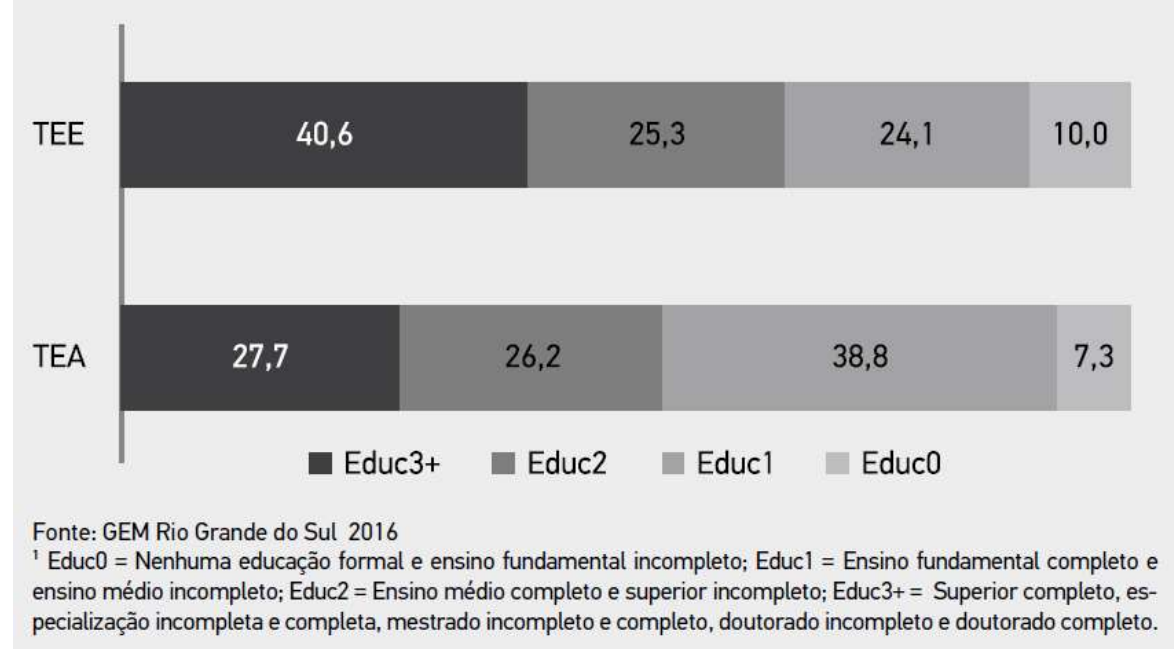

Fonte: GEM RS 2016.

Ao serem avaliadas as condições para abertura e manutenção do negócio, a Tabela 3 apresenta os indicativos dos principais fatores limitantes.

Tabela 3: Principais fatores limitantes para a abertura e manutenção de novos negócios segundo os especialistas entrevistados - Rio Grande do Sul - 2016

\begin{tabular}{|l|r|r|}
\hline \multicolumn{1}{|c|}{ Principais obstáculos } & \multicolumn{2}{|c|}{$\%$ dos especialistas } \\
\hline & $\begin{array}{c}\text { Avaliando Rio } \\
\text { Grande do Sul }\end{array}$ & \begin{tabular}{c} 
Avaliando o Brasil \\
\hline Políticas governamentais e programas
\end{tabular} \\
\hline Apoio Financeiro & 87,0 & 91,3 \\
\hline Educação e Capacitação & 30,4 & 26,1 \\
\hline
\end{tabular}

Fonte: GEM Rio Grande do Sul 2016

'Percentual dos respondentes que mencionaram o fator. 0 especialista pode ter mencionado mais de um fator.

${ }^{2}$ Especialistas entrevistados pelo estado do RS avaliando o estado e o Brasil.

${ }^{3}$ Políticas governamentais e programas: Políticas Governamentais; Programas; Diferenças devida ao porte da Empresa; Internacionalização; Custos do trabalho, Acesso e Regulamentação.

Fonte: GEM RS 2016.

Em 2016, no Rio Grande do Sul, uma parcela expressiva dos especialistas, avaliando as condições de empreender no estado e no Brasil, apontou como limitante o fator Políticas governamentais e programas $87,0 \%$ no estado e $91,3 \%$ no Brasil. Uma parcela bem menor indicou como limitante os fatores Apoio Financeiro (30,4\% e 26,1\%, respectivamente) e Educação e Capacitação (30,4\% tanto no estado quanto no Brasil). (GEM RS 2016) 
Conforme a Tabela 4 abaixo uma grande parcela dos gaúchos 79,9\% entende que os fatores limitantes da criação e manutenção dos novos negócios estão relacionados à dificuldade de acesso a recursos financeiros e à legislação brasileira.

\section{Tabela 4: Principais fatores limitantes para a abertura e manutenção de novos negócios segundo os empreendedores1 - Rio Grande do Sul - 2016}

\begin{tabular}{l|r|}
\hline \multicolumn{1}{|c|}{ Fatores } & \% de empreendedores \\
\hline Acesso a recursos financeiros (empréstimos ou financiamentos) & 42,4 \\
\hline Legislação e impostos (leis e carga tributária) & 37,5 \\
\hline $\begin{array}{l}\text { Fonte: GEM Rio Grande do Sul } 2016 \\
\text { 'Proporção dos empreendedores identificados na pesquisa com a população adulta. }\end{array}$ \\
\hline Fonte: GEM RS 2016.
\end{tabular}

$\mathrm{Na}$ opinião de uma expressiva parcela dos empreendedores gaúchos os principais fatores limitantes para a criação e manutenção de novos negócios são os seguintes: Acesso a recursos financeiros $42,4 \%$, e legislação e impostos 37,5\%. (GEM- RS, 2016).

Segundo relatório GEM Women's Report (2016/2017), estima-se que em 2016 havia 163 milhões de mulheres iniciando negócios em 74 economias em todo o mundo, enquanto 111 milhões estavam administrando empresas estabelecidas.

No Brasil ao analisarmos as taxas de empreendedorismo total por gênero em 2017 no Gráfico 3, verifica-se que os homens são ligeiramente mais empreendedores que as mulheres, uma diferença de quase três pontos percentuais. Entre os empreendedores estabelecidos essa diferença é superior a quatro pontos. Contudo se tomarmos isoladamente os empreendedores iniciais, elas superam os homens em quase um ponto percentual. Esse comportamento do empreendedorismo segundo o gênero, pode levantar algumas reflexões: seriam as mulheres menos persistentes na condução dos seus empreendimentos? Ou o ambiente para mulheres empreenderem ainda lhes é desfavorável e isso afeta a longevidade dos seus negócios? (GEM 2017). 
Gráfico 3: Taxas (em \%) específicas1 e estimativas2 (em milhões) do número de empreendedores por gêneros segundo estágios do empreendimento - Brasil - 2017.

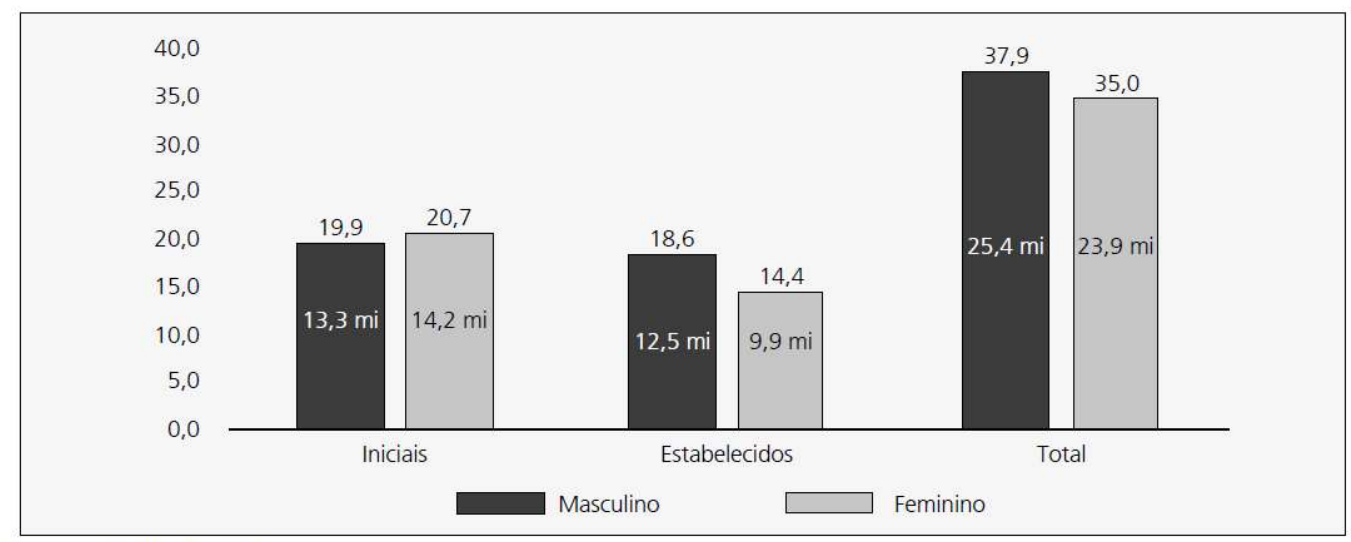

Fonte: GEM Brasil 2017

1 Percentual da população referente a cada categoria da população (ex. 19,9\% dos homens no Brasil são empreendedores iniciais).

2 Estimativa calculadas apartir de dados da população brasileira de 18 a 64 anos para o Brasil em 2017:135,4 milhões.Fonte: IBGE/Diretoria de Pesquisas. Projeção da população do Brasil e Unidades da Federação por sexo e idade para o período 2000-2030 (ano 2017 ).

Fonte: GEM 2017.

No Brasil, dentre os empreendedores iniciais predomina o gênero feminino $51,5 \%$. No caso dos empreendedores estabelecidos, $57,3 \%$ são homens. Nacionalmente observa-se uma tendência de aumento de mulheres na taxa de empreendedores iniciais como um dos fatos relevantes e recentes da sociedade brasileira.

No estado do Rio Grande do Sul, o levantamento do Global Entrepreneurship Monitor do Rio Grande do Sul (GEM RS, 2016) aponta que os empreendedores iniciais são $54,4 \%$ do gênero masculino, enquanto os empreendedores estabelecidos somam 57,1\%, conforme Gráfico 4 abaixo.

Gráfico 4: Distribuição percentual dos empreendedores iniciais (TEA) e estabelecidos (TEE) segundo gênero - Rio Grande do Sul - 2016.

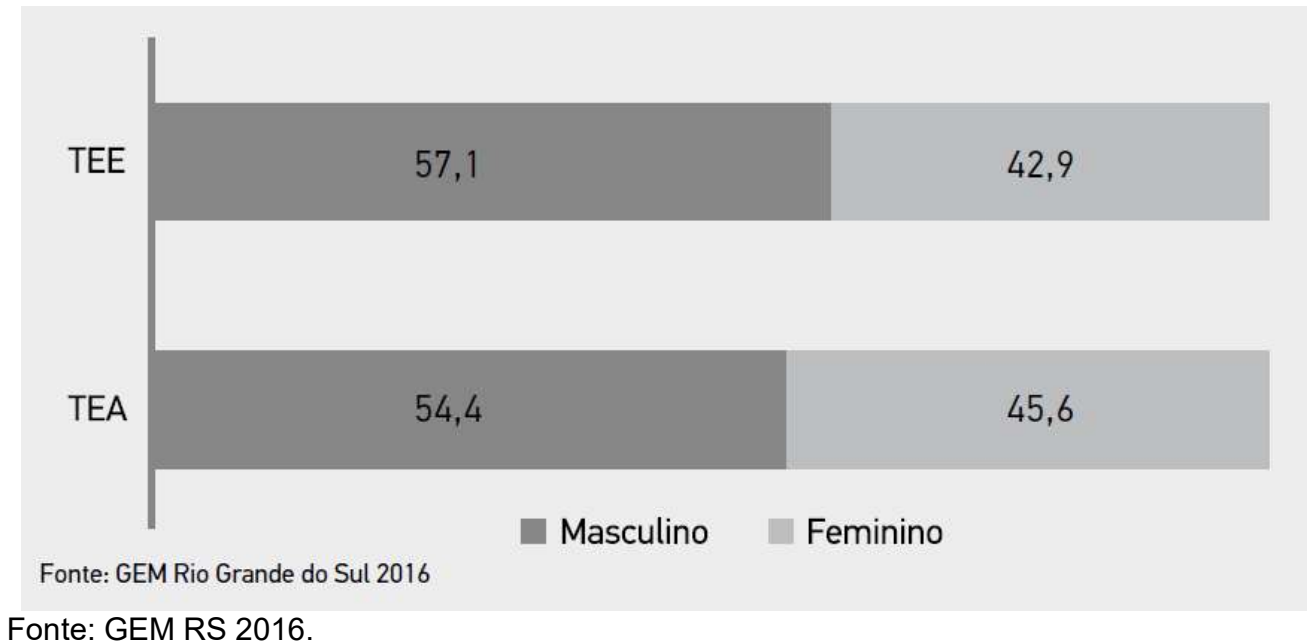

Fonte: GEM RS 2016. 
No que se refere à faixa etária, a distribuição dos empreendedores iniciais apresentou em 2016 um perfil bem mais jovem do que a dos estabelecidos Gráfico 5 (Gráfico 4 do GEM RS 2016). Dentre os empreendedores iniciais $18,2 \%$ se encontram na faixa etária de 18 a 24 anos. Entre os estabelecidos esse percentual se restringe a $2,2 \%$. Nesse contexto, estima-se que nessa faixa etária existem no estado 167,2 mil empreendedores iniciais e 22,4 mil estabelecidos. A partir da faixa etária de 45 a 54 anos esta situação se inverte: a proporção de empreendedores estabelecidos em relação ao total desses empreendedores é maior. Na faixa etária de 55 a 64 anos encontram-se $24,8 \%$ do total de empreendedores estabelecidos e somente $9,3 \%$ do total dos iniciais. Esses percentuais correspondem a 252,2 mil e 85,4 mil empreendedores estabelecidos e iniciais, respectivamente. Como pode ser constatado, a quantidade de empreendedores gaúchos de maior idade é expressiva. (GEM RS 2016)

\section{Gráfico 5: Fonte GEM Rio Grande do Sul 2016}

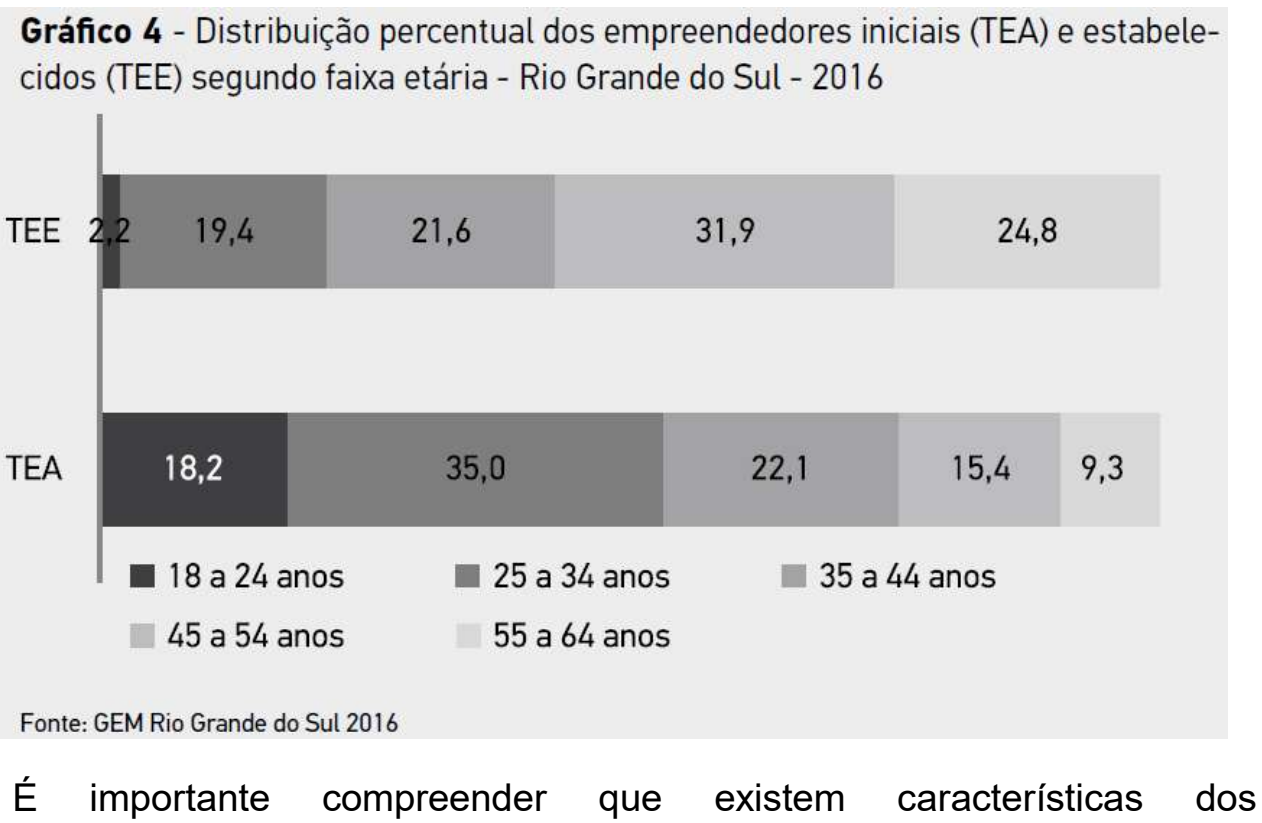
empreendimentos iniciais e estabelecidos gaúchos no que se refere aos seguintes quesitos: faturamento e porte; atividade econômica; e potencial de inovação. Na Tabela 5 (Tabela 4 do GEM RS 2016) abaixo é possível observar os dados dos empreendedores iniciais.

"Os empreendedores considerados como prováveis microempresas (área cinza total na Tabela 4), representando $98,0 \%$ dos empreendedores iniciais, ou que podem ser considerados como prováveis microempreendedores individuais $\mathrm{MEI}$ (área menor em cinza escuro na tabela), representando $87,0 \%$ dos 
empreendedores iniciais, estão concentrados principalmente nas faixas de faturamento de R\$ 1 mil a R\$ 2 mil por mês $67,1 \% "$.

(GEM RS 2016)

Tabela 5: Faturamento anual e número de empregados dos empreendedores iniciais - Rio Grande do Sul - 2016. Fonte: GEM RS 2016.

Tabela 4 - Faturamento anual e número de empregados dos empreendedores iniciais - Rio Grande do Sul- 2016

\begin{tabular}{|c|c|c|c|c|c|c|}
\hline \multirow[b]{2}{*}{ Faturamento Anual } & \multirow{2}{*}{ 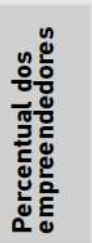 } & \multicolumn{5}{|c|}{ Número de empregados } \\
\hline & & 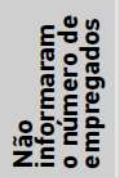 & 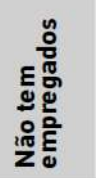 & 1 & $\underset{2 \mathrm{a} 5}{\mathrm{De}}$ & 6 ${ }^{\mathrm{De}} 10$ \\
\hline Não informaram faturamento & 2,0 & 0,0 & 0,8 & 0,8 & 0,4 & 0,0 \\
\hline Ainda não faturou nada & 20,7 & 19,9 & 0,0 & 0,4 & 0,4 & 0,0 \\
\hline Até $\mathrm{R} \$ 12.000,00$ & 51,6 & 2,5 & 31,0 & 14,9 & 2,8 & 0,4 \\
\hline De $R \$ 12.000,01$ a $R \$ 24.000,00$ & 15,5 & 0,0 & 8,2 & 4,1 & 2,9 & 0,4 \\
\hline De $R \$ 24.000,01$ a $R \$ 36.000,00$ & 6,1 & 0,0 & 2,8 & 1,6 & 1,2 & 0,4 \\
\hline De $R \$ 36.000,01$ a $R \$ 48.000,00$ & 2,1 & 0,0 & 0,8 & 0,0 & 0,8 & 0,4 \\
\hline De $R \$ 48.000,01$ a $R \$ 60.000,00$ & 1,2 & 0,0 & 0,4 & 0,4 & 0,4 & 0,0 \\
\hline De $R \$ 60.000,01$ a $R \$ 100.000,00$ & 0,0 & 0,0 & 0,0 & 0,0 & 0,0 & 0,0 \\
\hline De $R \$ 100.000,01$ a $R \$ 240.000,00$ & 0,8 & 0,0 & 0,0 & 0,4 & 0,4 & 0,0 \\
\hline Acima de $\mathrm{R} \$ 240.000,00$ & 0,0 & 0,0 & 0,0 & 0,0 & 0,0 & 0,0 \\
\hline Total & 100,0 & 22,3 & 44,0 & 22,7 & 9,3 & 1,6 \\
\hline
\end{tabular}

Fonte: GEM Rio Grande do Sul 2016

Nota: a área cinza total compreende empreendimentos considerados como os prováveis microempresas representando $98,0 \%$ do total de empreendedores iniciais e a área menor em cinza escuro compreende empreendimentos consideradosprováveis microempreendedores individuais (MEI), representando $87,0 \%$ do total de empreendedores iniciais.

No que se refere aos empreendedores estabelecidos, uma parcela expressiva $88,1 \%$ não tem empregados $66,7 \%$ ou possuem somente um $21,4 \%$. Apenas $8,2 \%$ e $1,5 \%$ têm de 2 a 3 empregados ou de 4 a 7 empregados, respectivamente. No entanto, alguns desses empreendedores $0,8 \%$ chegam a ter de 43 a 50 empregados. Tabela 6 (Tabela 5 do GEM RS 2016) abaixo. (GEM RS 2016)

Os empreendedores considerados como prováveis microempresas (área cinza total na Tabela 5), representando $94,4 \%$ dos empreendedores estabelecidos, ou que podem ser considerados como prováveis microempreendedores individuais - MEI (área menor em cinza escuro na tabela), representando $83,7 \%$ dos empreendedores iniciais, estão fortemente concentrados nas faixas de faturamento de $\mathrm{R} \$ 1$ mil a $\mathrm{R} \$ 2$ mil por mês $71,7 \%$. (GEM RS, 2016) 
Tabela 5 - Faturamento anual e número de empregados dos empreendedores estabelecidos - Rio Grande do Sul - 2016

\begin{tabular}{|c|c|c|c|c|c|c|c|}
\hline \multirow[b]{2}{*}{ Faturamento Anual } & \multirow{2}{*}{ 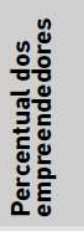 } & \multicolumn{6}{|c|}{ Número de empregados } \\
\hline & & 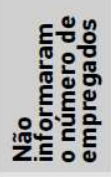 & 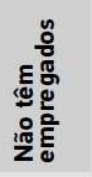 & 1 & $\begin{array}{c}\mathrm{De} \\
2 \mathrm{a} 3\end{array}$ & $\begin{array}{c}\mathrm{De} \\
4 \mathrm{a} 7\end{array}$ & $\begin{array}{c}\mathrm{De} \\
43 \text { a } 50\end{array}$ \\
\hline Não informaram faturamento & 5,6 & 0,4 & 4,1 & 0,4 & 0,7 & 0,0 & 0,0 \\
\hline Ainda não faturou nada & 0,0 & 0,0 & 0,0 & 0,0 & 0,0 & 0,0 & 0,0 \\
\hline Até $\mathrm{R} \$ 12.000,00$ & 51,0 & 1.1 & 38,6 & 9,9 & 1,1 & 0,0 & 0,4 \\
\hline De $R \$ 12.000,01$ a $R \$ 24.000,00$ & 20,7 & 0,0 & 12,9 & 5,2 & 2,6 & 0,0 & 0,0 \\
\hline De $R \$ 24.000,01$ a $R \$ 36.000,00$ & 11,2 & 0,0 & 7,0 & 3,4 & 0,7 & 0,0 & 0,0 \\
\hline De $R \$ 36.000,01$ a $R \$ 48.000,00$ & 5,6 & 0,0 & 2,6 & 1,1 & 1,5 & 0,4 & 0,0 \\
\hline De $R \$ 48.000,01$ a $R \$ 60.000,00$ & 3,0 & 0,0 & 1,1 & 0,8 & 0,4 & 0,7 & 0,0 \\
\hline De $R \$ 60.000,01$ a $R \$ 100.000,00$ & 1,5 & 0,0 & 0,0 & 0,4 & 0,4 & 0,4 & 0,4 \\
\hline De $R \$ 100.000,01$ a $R \$ 240.000,00$ & 1,1 & 0,0 & 0,4 & 0,3 & 0,4 & 0,0 & 0,0 \\
\hline De $R \$ 240.000,01$ a $R \$ 360.000,00$ & 0,4 & 0,0 & 0,0 & 0,0 & 0,4 & 0,0 & 0,0 \\
\hline Acima de $R \$ 360.000,00$ & 0,0 & 0,0 & 0,0 & 0,0 & 0,0 & 0,0 & 0,0 \\
\hline Total & 100,0 & 1,4 & 66,7 & 21,4 & 8,2 & 1,5 & 0,8 \\
\hline
\end{tabular}

Fonte: GEM Rio Grande do Sul 2016

Nota: a área cinza total compreende empreendimentos considerados como os prováveis microempresas representando $94,4 \%$ do total de empreendedores estabelecidos e a área menor em cinza escuro compreende empreendimentos considerados prováveis microempreendedores individuais (MEI),

representando $83,7 \%$ do total de empreendedores estabelecidos.

Por fim, uma vez tomada a decisão de empreender e vislumbrada a oportunidade, o empreendedor parte para elaboração de um plano de negócio, a fim de esse ser o condutor do caminho que o empreendimento deve seguir. Logo, é uma maneira de minimizar as chances de riscos, desde que o mesmo se adeque constantemente à realidade do negócio, sendo esse um dos principais desafios do empreendedor. Salim, C. Nasajon, C. Salim, H. Mariano, S. (2004).

O processo de empreender pode ser resumido em etapas segundo (SALIM et al, 2004):

- Despertar da motivação para a criação do próprio negócio;

- Desenvolvimento da ideia ou processo visionário;

- Validação da ideia;

- Definição da escala de operação e identificação dos recursos necessários;

- Elaboração do plano de negócio, que apresenta a formatação do empreendimento para sua negociação interna e externa;

- Operacionalização do plano de negócios, dando-se início à empresa;

- Consolidação e sobrevivência;

O empreendedor de sucesso possui todo um elenco de características, segundo Dornelas (2008), as quais são apontadas na Tabela 7. 
Tabela 7: Caraterísticas de um empreendedor de sucesso segundo Dornelas (2008)

\begin{tabular}{|c|c|c|c|}
\hline \multicolumn{4}{|c|}{ Características dos Empreendedores de Sucesso } \\
\hline São visionários & Sabem tomar decisões & $\begin{array}{c}\text { São individuos que } \\
\text { fazem a diferença }\end{array}$ & $\begin{array}{c}\text { São lideres e } \\
\text { formadores de equipe }\end{array}$ \\
\hline $\begin{array}{c}\text { Sabem explorar ao máximo } \\
\text { as oportunidades }\end{array}$ & $\begin{array}{c}\text { São determinados e } \\
\text { dinâmicos }\end{array}$ & São dedicados & $\begin{array}{c}\text { Planejam, planejam, } \\
\text { planejam }\end{array}$ \\
\hline $\begin{array}{c}\text { São otimistas e } \\
\text { apaixonados pelo que } \\
\text { fazem }\end{array}$ & $\begin{array}{c}\text { São independentes e } \\
\text { constroem o próprio destino }\end{array}$ & Ficam ricos & $\begin{array}{c}\text { São bem relacionados } \\
\text { (networking) }\end{array}$ \\
\hline $\begin{array}{c}\text { Criam valor para a } \\
\text { sociedade }\end{array}$ & Assumem riscos calculados & São organizados & Possuem conhecimento \\
\hline
\end{tabular}

Fonte: Adaptado de Dornelas (2008)

Segundo Hisrich, Peters e Shepherd (2009, p. 36), "o papel do empreendedorismo no desenvolvimento econômico envolve mais do que apenas o aumento da produção e de renda per capita; envolve iniciar e constituir mudanças na estrutura do negócio e da sociedade". Essas mudanças permitem que parte da riqueza produzida seja distribuída entre os indivíduos que fazem parte do processo.

Neste ponto ressaltam-se as características e comportamentos dos empreendedores que segundo Dornelas (2005), são: inovação, liderança, capacidade de analisar riscos, independência, criatividade, autoconfiança, orientação para resultados, originalidade, iniciativa, flexibilidade, habilidade em situações adversas, capacidade de aprendizagem, comprometimento, planejamento aguçado, possuidor de redes de contato, criação de valor para a sociedade, entre outros.

\subsubsection{Empreendedorismo Feminino e Desafios}

Empreendedorismo feminino pode ser considerado como qualquer ação empreendedora que é realizada e/ou liderada especialmente por mulheres. Carland, Carland e Card (2005) evidenciaram que as mulheres têm encontrado diversas alternativas para explorar o empreendedorismo e atingir o sucesso. Elas estão aprendendo a equilibrar as várias demandas para o seu tempo e encontrando força nos números por colaborar umas com as outras.

Com o passar do tempo, alguns valores mudaram na família e no mercado de trabalho, como a necessidade da mulher trabalhar para ajudar o homem no sustento da casa. Com isso, houve um crescimento no empreendedorismo do gênero feminino (AVENI, NUNES \& CRUZ, 2012).

Segundo a pesquisa Donos de Negócio no Brasil, análise de gênero (que utiliza dados da Pnad/IBGE de 2016) o número de brasileiras empresárias 
cresceu 34\% entre 2001 e 2014, enquanto o aumento de homens nesta situação, no mesmo período, foi de 14\%. Elas empreendem mais em casa $35 \%$, são mais qualificadas que os homens empresários e dedicam menos tempo ao negócio (34 horas semanais, enquanto os homens trabalham 42 horas por semana). (SEBRAE 2016).

Segundo Moore e Buttner (apud JONATHAN, 2003), o empreendedorismo feminino gera emprego, riqueza, promove inovação e contribui para o desenvolvimento socioeconômico dos países.

Jonathan (2011) considera em seus estudos que a mulher empreendedora tem um comportamento considerado como 'inovativo' - ou seja, um comportamento inovador, caracterizado como inovador e desafiador em tudo que se relaciona às regras existentes para a resolução dos problemas que vão surgindo no processo ou no contexto em que atuam.

Gomes e Santana (2009) destacam que uma das principais razões para que a mulher venha a ter o próprio negócio é a flexibilidade de horários, pois dessa forma poderá compatibilizar o trabalho e a família. Para Strobino e Teixeira (2014) são raras as empreendedoras que têm a fronteira entre o trabalho e a vida pessoal, ou a vida em família, bem definida, e como consequência, geralmente o conflito trabalho-família é defrontado. Administrar a casa, cuidar da família e ter atividades fora do lar são características típicas da mulher contemporânea (JONATHAN, 2011).

Gomes, Guerra \& Vieira (2011) buscaram compreender como as mulheres percebem as motivações que as levaram ao empreendedorismo. Eles partem de estudos anteriores para definir como principais motivos, a realização pessoal, a percepção de uma oportunidade de mercado, a dificuldade de ascensão na carreira, a necessidade de sobrevivência e por último a possibilidade de conciliar trabalho e família.

Mesmo sendo afetadas pela restrição de tempo destinado aos filhos e às preocupações da casa, as mulheres acreditam que empreender oferece mais vantagens, como mais liberdade, realização, autonomia e independência financeira, além da satisfação com a atividade empreendedora sobre suas vidas (SILVEIRA et al, 2007). O autor ainda reforça que as mulheres possuem forte motivação para empreender, o que faz que elas, mesmo sendo afetadas pela restrição de tempo destinado aos filhos e as preocupações da casa, empreendam.

Em relação a natureza dos empreendimentos femininos, estão situados nas áreas de prestação de serviços como, serviços educacionais, consultoria 
ou relações públicas. (HISRICH; PETERS; SHEPHERD, 2009).

Tiedge (2004) aponta que as mães que trabalham frequentemente fazem uso de cinco estratégias para lidar com as situações tensas entre as causas do trabalho e as do papel que exercem com a maternidade. São elas:

(a) estratégia super-mulher, que envolve buscar atingir com eficiência todas as expectativas vinculadas aos diferentes papéis sociais;

(b) planejamento e administração do tempo, que implica em otimizar o desempenho dos papéis;

(c) reinterpretação cognitiva das demandas, envolvendo, por exemplo, diminuir seu próprio padrão de exigências;

(d) afastamento de atividades menos importantes, que pode incluir não assumir novas responsabilidades; e

(e) estratégia multitarefa, que envolve desempenhar várias atividades ao mesmo tempo.

Embora seja crescente o número de mulheres que estão à frente de um negócio, elas ainda precisam vencer inúmeros desafios e dificuldades. De acordo com o estudo feito por Gomes, Santana e Silva (2005), as mulheres enfrentam alguns obstáculos ao se tornarem empreendedoras, tais como:

1. dificuldades de autoconceito e aceitação;

2. falta de suporte afetivo e social;

3. dificuldade para atuar no mercado internacional;

4. dificuldade de financiamento;

5. dificuldade de acesso a redes e falta de mentores;

6. tamanho das empresas;

7. falta de tempo;

8. dificuldade em conciliar trabalho e família;

9. dilema entre a obrigação e o desejo;

10. ausência de modelos de referência de empreendedoras.

Com relação ao fator de obtenção de crédito junto a banco e investidores, as mulheres, historicamente, encontram mais dificuldades do que os homens. Por isso, geralmente a principal fonte de recurso do gênero feminino são seus bens e suas economias pessoais. (Hisrich; Peter; Shepherd, 2009).

Para Machado, St Cyr, Mione \& Alves (2003) é necessário elaborar programas de treinamento e financiamentos voltados para mulheres empreendedoras, visando o crescimento do negócio.

Algumas mulheres demoram mais para investirem em seus negócios por 
serem mais temorosas em considerarem empréstimos, porém o empréstimo é um elemento de risco que possibilita levar o empreendimento de um estágio para outro, promovendo seu crescimento (CARREIRA et al, 2015).

No estudo do Sebrae e do IBPQ (GEM 2016), os técnicos também listaram obstáculos retratados por mulheres empreendedoras e recomendam maior suporte.

"[As mulheres] conseguem criar novos negócios, porém enfrentam dificuldades para fazer seus empreendimentos prosperarem. Tal fenômeno pode estar associado às condições relatadas, como preconceito de gênero, menor credibilidade pelo fato de o mundo dos negócios ser mais tradicionalmente associado a homens, maior dificuldade de financiamento e dificuldade para conciliar demandas da família e do empreendimento. Essa situação aponta para a necessidade de maiores investimentos para dar suporte", ressalta a pesquisa. (AGÊNCIA BRASIL, 2017)

O presidente do Sebrae, Guilherme Afif Domingos, afirma que "em tempos de crise o empreendedorismo é uma alternativa para vários brasileiros que perderam o emprego ou buscam uma renda extra. No caso das mulheres, ele destaca que a solução pode ser mais viável que um emprego com horário rígido, já que muitas delas têm de fazer a chamada jornada dupla. Quem quer fazer carreira em uma empresa tem que lidar com a disciplina dos horários, o que não facilita". (AGÊNCIA BRASIL, 2017).

No âmbito do apoio, as mulheres costumam mencionar primeiramente seu cônjuge e amigos íntimos. Elas também contam com outras fontes de suporte e informação, como grupos profissionais femininos e associações comerciais. (HISRICH; PETERS; SHEPHERD, 2009).

No Brasil existe a plataforma de apoio ao empreendedorismo feminino, a Rede Mulher Empreendedora (RME, 2018), que oferece às empreendedoras que se cadastram, todo suporte necessário como sites com conteúdo relevantes e de qualidade, promove eventos de networking, cursos, mentorias, realizam parcerias com empresas que acreditam na causa do empreendedorismo feminino para levar oportunidades e facilidades para as mulheres; disponibiliza espaço publicitário em destaque no site, por meio de nosso marketplace; faz indicações para fomentar o comércio entre pequenas mulheres donas de negócio.

Segundo a fundadora da RME, Ana Fontes, em entrevista ao portal 
Brasil Econômico:

"Empreender é muito solitário e, para as mulheres, ainda mais. Nós acabamos assumindo todos os outros papéis e complicamos um pouco mais a nossa vida. Se não tivermos o apoio e a colaboração de outras empreendedoras, fica bem difícil empreender. Esses movimentos são ótimos para mulheres trocarem experiências com quem está passando pela mesma fase, fazer parcerias e aumentar o networking". (BRASIL ECONÔMICO, 2017)

Portanto, mais do que como o simples ato de empreender, é importante entender o empreendedorismo feminino como um importante instrumento de transformação social das mulheres.

\subsection{Perfil Empreendedor Feminino}

Filion (2000, apud DOLABELA, 1999, p. 70) acredita que as características de um empreendedor variam de acordo com as atividades que o empreendedor realiza. Para Dolabela (1999), as características empreendedoras podem ser adquiridas e desenvolvidas. A preocupação de identificar o perfil do empreendedor de sucesso auxilia no processo de aprender a agir, adotando comportamentos e atitudes adequadas para se tornar um.

Pinchot (1985, apud HIRSCH; PETERS 2004, p. 61) em um comparativo entre as características do Gerente Tradicional, do Empreendedor e do Intraempreendedor, levanta interessantes comentários a respeito dos empreendedores. Dentre estes comentários destacam-se:

- os principais motivos dos empreendedores para criarem negócios: querer independência, oportunidade de criar e dinheiro;

- $\quad$ a orientação de tempo: sobrevivência e crescimento do negócio entre cinco e 10 anos;

- a atividade: envolvimento direto;

- o risco: assumem riscos moderados;

- $\quad$ o status: nenhuma preocupação;

- $\quad$ as falhas e erros: lidam bem com isso;

- $\quad$ as decisões: seguem seus sonhos;

- a quem serve: a si e aos clientes;

- a história familiar: experiência empresarial em pequena empresa, profissional ou fazenda; 
- o relacionamento com os outros: transações e acordos como relacionamento básico.

Em outra visão, Dornelas (2003), define que o empreendedor de sucesso possui características extras. Além dos atributos do administrador, e alguns atributos pessoais que somados a características sociológicas e ambientais permitem a realização da diferenciação e inovações dentro da corporação. Algumas dessas características dos empreendedores de sucesso segundo Dornelas:

- $\quad$ possuem visão de longo prazo para o negócio onde está envolvido e tem a habilidade de implementar seus sonhos;

- $\quad$ sabem tomar decisões;

- não são inseguros;

- $\quad$ sabem lidar nos momentos de adversidades;

- $\quad$ indivíduos que fazem a diferença;

- $\quad$ assumem risco;

- São otimistas e apaixonados pelo que fazem, adoram seu trabalho,

- $\quad$ são auto determinadores;

- $\quad$ são dedicados;

- $\quad$ são líderes e formadores de equipes, tem um senso de liderança incomum, são adorados pelos subordinados;

- são bem relacionados (networking), sabem construir uma rede de contatos;

- $\quad$ são organizados; planejam muito cada passo de suas atividades;

- são planejadas:

- possuem conhecimento, são sedentos pelo saber e aprendem continuamente;

- lideram;

- criam valor para a sociedade, gera empregos, dinamizam a economia,

- $\quad$ inovam sempre usando sua criatividade em busca de solução.

A Organização das Nações Unidas - ONU, criou uma metodologia voltada para o desenvolvimento de características do comportamento empreendedor, para a identificação de novas oportunidades de negócio e também para gestores e líderes que desejam desenvolver competências empreendedoras. Nela são identificadas e trabalhadas as 10 características de um empreendedor de sucesso de acordo com estudos da ONU (EMPRETEC, SEBRAE 2010), são elas:

Características apontadas pela ONU como de um empreendedor de 
sucesso:

1- Busca oportunidades e toma a iniciativa: o empreendedor faz o que deve ser feito antes de ser solicitado ou forçado, age para expandir o negócio, aproveita as oportunidades novas para começar um negócio.

2- Corre riscos calculados: avalia as alternativas, age para controlar os resultados, toma riscos moderados.

3- Exige qualidade e eficiência: age de maneira a realizar ações, desenvolve procedimentos para assegurar que o trabalho seja executado a tempo e que atenda aos padrões de qualidade.

4- É persistente: o empreendedor age diante de um obstáculo significativo, assume responsabilidade pessoal pelo desempenho necessário para atingir metas e objetivos.

5- É comprometido: faz sacrifício pessoal para completar as metas que foram determinadas, se esmera em manter os clientes satisfeitos e coloca em primeiro lugar a boa vontade a longo prazo, acima do curto prazo.

Características relativas ao planejamento:

6- Busca de informações: está sempre buscando novos métodos e novas informações para aprimorar o serviço.

7- Estabelecimento de metas: o empreendedor estabelece metas e objetivos que são desafiantes.

8- Planejamento e monitoramento sistemático: planeja dividindo tarefas de grande porte em subtarefas com prazos definidos, constantemente revisa seus planos levando em conta os resultados obtidos e as mudanças circunstanciais, utiliza registros financeiros para tomar decisões.

Características relativas ao poder:

9- Persuasão e rede de contatos: o empreendedor utiliza estratégias para influenciar ou persuadir pessoas. Trabalha com pessoas-chave, age para desenvolver e manter relações comerciais.

10- Independência e Autoconfiança: o empreendedor busca autonomia em relação a normas e controles de terceiros, mantém seu ponto de vista, expressa confiança na sua própria capacidade de enfrentar um desafio.

De acordo com Salim, et al (2004), existe um conjunto de atitudes atreladas ao empreendedor. Consideram dez mandamentos e qualidades a empresários bem-sucedidos:

1. Assumir riscos: "Os riscos fazem parte de qualquer atividade e é preciso saber lidar com eles."

2. Identificar oportunidades: "Ficar atento e perceber, no momento certo, as 
oportunidades que o mercado oferece e reunir as condições propícias para a realização de um bom negócio é outra marca importante do empresário bem sucedido."

3. Conhecimento: "Quanto maior for o domínio de um empresário sobre um ramo de negócio, maior é sua chance de êxito."

4. Organização: "Ter capacidade de utilizar recursos humanos, materiais financeiros e tecnológicos - de forma racional."

5. Tomar decisões: "O sucesso de um empreendimento, muitas vezes está relacionado com a capacidade de decidir corretamente."

6. Liderança: "Liderar é saber definir objetivos, orientar tarefas, combinar métodos, estimular as pessoas no rumo das metas traçadas e favorecer relações equilibradas dentro da equipe de trabalho, em torno do empreendimento."

7. Dinamismo: "Um empreendedor de sucesso nunca se acomoda, para não perder a capacidade de fazer com que simples ideias se concretizem em negócios efetivos."

8. Independência: "O empreendedor deve ser livre, evitando protecionismos que, mais tarde, possam se tornar obstáculos aos negócios. "

9. Otimismo: "Capazes de enfrentar obstáculos, o empresário de sucesso, em vez de imaginar o fracasso."

10. Tino empresarial: "O que muita gente acredita ser um sexto sentido, intuição, faro empresarial, típico de gente bem-sucedida nos negócios é, na maioria das vezes, a soma de todas as qualidades descritas".

No âmbito feminino, as mulheres apresentam um perfil positivo ao empreendedorismo, uma vez que são criativas, comunicativas, flexíveis e tolerantes no trabalho (Hisrich; Peters e Shepherd, 2009) e ainda, apresentam desempenho positivo frente ao gerenciamento de empreendimentos (Machado, 2002). Ainda de acordo com a autor, as mulheres, por sua vez, são flexíveis e tolerantes, ao passo que os homens opinativos e persuasivos.

Segundo Wiesel (2010), outras características que contribuem para o empreendedorismo feminino são:

- Intensidade. Em tudo que fazem, elas se dedicam integralmente. O campo de visão da mulher por mais amplo que seja, sabe ser restrito. Este fato, passa para quem está interagindo com ela a sensação de que a comunicação não é virtual, ao contrário, está acontecendo em tempo real. A intensidade também está nos sentimentos que passa. 
- Afetividade. Sabe como ninguém ser afetuosa e guerreira, gentil e exigente.

- Aptidão para a negociação. Sabe apresentar as ideias levando em conta prazos e orçamentos.

- Humildade. Valoriza as ideias dos outros, e sabe dizer "não sei fazer tal atividade" e pede ajuda - mostrando-se pronta para aprender.

- Responsabilidade. Cumprimento de prazos, prometendo o que poderá cumprir.

- Alto astral. Sua necessidade de comunicação oral impulsiona risadas e boas histórias. Ela sempre tem um comentário a mais por fazer. Isto torna o ambiente mais leve.

- Excelente ouvinte. Apesar de falar muito, também sabe ouvir e compreende com mais facilidade as necessidades dos outros. Ela sabe como dar um tempo aos outros e também para si.

- Importância ao autoconhecimento. Por ser extremamente assertiva a mulher analisa constantemente suas habilidades e dificuldades.

- Organização. Começo, meio e fim, esta é a sequência e a dinâmica de suas ações.

- Flexibilidade. Por sua necessidade constante em cumprir vários papéis (dona de casa, mãe, esposa, profissional, etc) desenvolveu a capacidade de adaptação as mais variadas situações.

De acordo como portal Governo do Brasil (2018) um levantamento do Sebrae traçou o perfil das empresárias, que são sobretudo jovens: $40 \%$ delas são mulheres com menos de 34 anos que estão concentradas principalmente em quatro áreas de atuação: restaurantes 16\%, serviços domésticos $16 \%$, cabeleireiros $13 \%$ e comércio de cosméticos $9 \%$. A maior parte empreende dentro de casa $35 \%$.

Os perfis das empreendedoras brasileiras, de acordo com a Rede de Mulher Empreendedora (2016), têm em média, 39 anos, quase $80 \%$ têm ensino superior completo ou mais, sendo que mais da metade $55 \%$ têm filhos. Das que já são mães, $75 \%$ dizem que decidiram empreender depois da maternidade.

O destemor e a autoconfiança presentes nos discursos das empreendedoras reproduzem o que inúmeros pesquisadores observaram ser características do perfil do empreendedor, independentemente de gênero ou de nacionalidade (Hisrich \& Peters, 2002; Weeks \& Seiler, 2001) 
Machado (1999 apud PÑALOZA; DIÓGENES; SOUZA, 2008, P. 154), atrela as empreendedoras femininas características psicológicas e comportamentais ditas como: "persistentes, com alto desejo de realização e independência, ativas, persuasivas, inovadoras, precisas e adaptáveis às mudanças, e acreditam ainda que seu destino seja fruto de suas ações. "

Outras características atribuídas às mulheres são: expressividade, conectividade, amabilidade e realização, derivando uma maior facilidade na comunicação, segundo Gupta et al (2005 apud PEÑALOZA; DIÓGENES; SOUZA, 2008).

Segundo (Jonathan, 2003), questões financeiras e o crescimento da empresa suscitam inseguranças e levam as empreendedoras brasileiras a terem um comportamento de cautela face ao desenvolvimento do negócio.

Pode-se constatar que a mulher passou a ser importante colaboradora, ou até mesmo a principal fonte de renda no orçamento familiar por meio dos resultados de seus empreendimentos.

\subsection{Liderança}

Liderança é o processo de influenciar as atividades de um grupo organizado em direção à realização de um objetivo. (YUKL, 1998).

A liderança é função das necessidades existentes em uma determinada situação e consiste em uma relação entre um indivíduo e um grupo. Trata-se de uma relação funcional. Essa relação funcional somente existe quando um líder é percebido por um grupo como o possuidor ou o controlador de meios para a satisfação de suas necessidades. (CHIAVENATO, 2003, p.149).

Teixeira (2005, p.163) diz que "liderança é o processo de influenciar outros de modo a conseguir que eles façam o que o líder quer que seja feito, ou ainda, a capacidade de influenciar um grupo a atuar no sentido da prossecução dos objetivos do grupo". Ainda na perspectiva de Teixeira (2005), liderar é uma das diversas tarefas de um gestor, o que leva a que, devido à importância da liderança na gestão de uma organização, por vezes se confunda liderança com gestão.

Segundo Northouse (2007), a Teoria do Estilo enfatiza o comportamento do líder. Este comportamento se subdivide em estilo voltado a Tarefa e estilo voltado a Relacionamento. O objetivo principal desta teoria é explicar como os líderes combinam estes dois comportamentos para influenciar seus seguidores a atingirem as metas estabelecidas. 
Segundo os estudos da Ohio State, principalmente de Stodgill (1974), os comportamentos do líder se dividem em comportamentos estruturais (de tarefa), tais como organização do trabalho, fornecimento de estrutura, definição de responsabilidades, e comportamentos de consideração (ou de relacionamento), tais como camaradagem, respeito, confiança e entrosamento entre líderes e seguidores.

A capacidade de liderança pode ser identificada a partir de traços, e podem diferenciar líderes de não-líderes com base nas qualidades e características pessoais. Os traços são: ambição e energia, desejo de liderar, honestidade e integridade, autoconfiança, inteligência, elevado automonitoramento, e conhecimentos relevantes para o trabalho. (ROBBINS, 2011)

Chiavenato (2003) ressalta que o líder deve inspirar confiança, possuir inteligência, percepção e decisão para exercer a liderança com sucesso

A confiança é considerada um atributo essencial à liderança, quando os seguidores confiam no seu líder eles buscam segui-lo e deixam se influenciar. A falta de confiança pode afetar negativamente o desempenho do grupo. Portanto, um líder não é capaz de liderar aqueles que não confiam nele. Existem três tipos de confiança: (ROBBINS, 2011)

- Confiança na intimidação: o liderado tem medo de receber alguma punição de autoridade dentro do ambiente de trabalho por não executar determinada tarefa.

- Confiança baseada no conhecimento: tem como base a informação. Informações adequadas sobre alguém a ponto de poder fazer previsões sobre seu comportamento. A previsibilidade aumenta a confiança.

- Confiança baseada na identificação: o nível mais alto de confiança é quando existe uma conexão emocional entre o líder e seus seguidores. Uma parte pode fazer as vezes a parte da outra ou agir um nome da outra. Existe uma lealdade muito forte nessa confiança e não havendo necessidade de um alto monitoramento e controle.

Para Gomes (2004, apud Munhoz 2000), um dos fatores de sucesso do empreendedorismo, passa pelo entendimento da questão de gênero, na compreensão de que as mulheres, de um modo geral, desenvolvem um estilo singular quando administram, haja vista que sua abordagem de liderança é fruto de um aprendizado desde a infância sobre valores, comportamentos e interesses voltados mais para a cooperação.

Os líderes são indivíduos que inspiram seus seguidores por meio de 
palavras, ideias e comportamentos, esses aspectos fazem parte de duas teorias de liderança: a carismática e a transformacional.

$\mathrm{Na}$ teoria de liderança carismática, o líder é visto com características heroicas por seus seguidores e os mesmos se sentem mais motivados e satisfeitos em relação ao trabalho que exercem. Porém a liderança carismática nem sempre consegue atingir altos níveis de desempenho. Segundo (ROBBINS, 2011), aos líderes carismáticos são atribuídas cinco características pessoais como:

- visão e articulação: são capazes de esclarecer a importância da visão em termos compreensíveis para os demais.

- risco pessoal: estão dispostos a correr riscos pessoais, sofrer altos custos e submeter ao auto sacrifício para atingir sua visão.

- sensibilidade ao ambiente: fazem avaliações realistas das limitações ambientais e recursos necessários para realização de mudança.

- sensibilidade para as necessidades dos liderados: são perceptíveis em relação às capacidades dos outros e sensíveis as suas necessidades e sentimentos.

- comportamentos não-convencionais: engajam em comportamentos que são percebidos como novidades e que vão contra as normas.

Os líderes transformacionais dão atenção às preocupações e às necessidades de desenvolvimento de cada um de seus liderados. São capazes de modificar a maneira de como seus seguidores enxergam as coisas, ajuda-os a buscar novas soluções para os antigos problemas, são entusiasmados, incitam e inspiram aos colaboradores a darem o máximo de si na busca dos objetivos do grupo. Esse tipo de liderança é capaz de provocar um efeito profundo e excelente sobre seus liderados pois inspiram os mesmos a transcender seus próprios interesses para 0 bem da organização.(ROBBINS, 2011). Suas principais características são:

- carisma: oferece uma visão e o sentido da missão, estimula o orgulho, ganha o respeito e a confiança.

- inspiração: comunica suas altas expectativas, utiliza símbolos para focar os esforços, expressa propósitos importantes de maneira simples.

- estímulo intelectual: promove a inteligência, a racionalidade e a cuidadosa resolução de problemas.

- consideração individualizada: dá atenção personalizada, trata cada funcionário individualmente, aconselha e orienta.

Outra teoria que pode ser abordada é a da liderança transacional, onde 
o líder conduz ou motiva seus seguidores na direção das metas estabelecidas por meio do esclarecimento dos papéis e da exigência do cumprimento das tarefas. Suas principais características são: (ROBBINS, 2011)

- recompensa contingente: negocia a troca de recompensas por esforço, promete recompensas pelo bom desempenho e reconhece as conquistas.

- administração por exceção (ativa): procura e observa desvios das regras e padrões, tomando as atitudes corretivas necessárias.

- administração por exceção (passiva): intervém apenas quando os padrões não são alcançados.

- laissez-faire: abdica das responsabilidades, evita a tomada de decisões.

A eficácia da liderança está relacionada positivamente à inteligência emocional do líder, em todos os níveis de seu desempenho no trabalho. Os grandes líderes demonstram sua inteligência emocional por meio de todos os cinco elementos principais:

- autoconsciência: é demonstrada através da autoconfiança, da auto avaliação realista e de um senso de humor voltado para a autocrítica.

- autogerenciamento: demonstrado através da integridade e confiabilidade, da capacidade de lidar bem com a ambiguidade e da abertura para mudanças.

- automotivação: demonstrada através da forte orientação para a conquista, do otimismo e de um alto comprometimento organizacional.

- empatia: demonstrada através da habilidade de gerar e reter talentos, da sensibilidade multicultural e de serviços voltados aos clientes e consumidores.

- habilidades sociais: demonstradas através da capacidade de liderar esforços para a mudança, da capacidade de persuasão e da competência na construção e liderança de equipes.

Segundo o autor (ROBBINS, 2011), o líder tem um importante papel na liderança de equipes pois precisa desenvolver habilidades como a paciência para compartilhar informações, confiar nos seus liderados, aprender a deixar a equipe sozinha e saber o momento certo para intervir. Possui quatro papéis específicos são eles:

- elementos de ligação com os componentes externos: colhe as informações de fontes externas e as compartilha com os membros da equipe.

- solucionadores de problemas: os líderes se reúnem aos seus seguidores para buscar junto a eles soluções para as dificuldades. 
- administradores de conflitos: ajudam a resolver o conflito minimizando os aspectos destrutivos dos conflitos internos da equipe.

- treinadores: definem muito bem os papéis, ensinam, torcem e oferece total apoio para ajudar seus colaboradores a melhorar seus desempenho no trabalho.

Segundo Lacombe $(2011$, p. 381) as empresas que não treinam e desenvolvem seus funcionários, podem enfrentar dificuldades competitivas por falta de gente preparada para seus cargos. Treinamento significa "o preparo da pessoa para o cargo" (Chiavenato 1999, p. 20), já a área de desenvolvimento se aproxima mais da educação que é o preparo da pessoa "da vida, para a vida e pela vida" (Chiavenato 1999, p. 20).

$O$ conceito de autoliderança aumentou com a popularização do uso das equipes. A premissa que baseia a teoria é de que os indivíduos são responsáveis, capazes e podem ter iniciativas sem a necessidade de chefes, regras ou regulamentos, desde que recebem o suporte adequado para monitorar e controlar o próprio comportamento (ROBBINS, 2011). Sendo assim os líderes podem criar pessoas autolideradas por meio de algumas sugestões:

- ser um modelo de autoliderança;

- estimular os funcionários a fixar metas próprias;

- estimular o uso de auto-recompensas para fortalecer e encorajar comportamentos desejáveis;

- criar padrões positivos de pensamento;

- criar um clima propício à autoliderança;

A teoria da atribuição da liderança diz que a liderança é simplesmente uma atribuição feita pelas pessoas acerca de outros indivíduos. Ou seja, as pessoas caracterizam os líderes como possuidores de alguns traços como inteligência, personalidade extrovertida, boa oratória, agressividade, compreensão e generosidade. Geralmente nessa teoria os líderes são considerados como coerentes e assertivos em suas decisões. (ROBBINS, 2011)

Os líderes possuem diferentes estilos de comportamento para liderar: liderança autocrática, liderança democrática e liderança liberal. Um dos grandes segredos para se tornar um líder eficaz é conseguir o equilíbrio desses três estilos, utilizando cada qual no momento adequado. A teoria situacional de liderança diz que para cada situação é necessário um tipo de 
liderança para alcançar a eficácia.

O empreendedor possui a iniciativa de criar um novo negócio, utilizando os recursos disponíveis, transformando o ambiente em que vive, socialmente e economicamente, assumindo riscos calculados e levando em conta também a possibilidade do empreendimento não dar certo. Portanto, o empreendedor deve agir por meio de uma liderança ética, com atitudes conscientes pensando no futuro, com responsabilidades sociais e ambientais.

\subsubsection{Liderança Feminina}

A liderança feminina tem evoluído e está bastante diferente, hoje o reconhecimento do papel da mulher, está em constante desenvolvimento no mercado de trabalho (FRANKEL, 2007).

Cirolini e Noro (2008) destacam que a presença da mulher no mercado de trabalho atual é um fato indiscutível e irreversível: a ascensão das mulheres marcou o final do século passado, buscando posições antes desempenhadas somente por homens; hoje, as mulheres empreendem e inovam seus próprios negócios ou exercem cargos de chefia com elevado grau de poder em organizações maiores, comprovando competência e habilidade na execução de suas atividades.

Frankel (2007) ainda define liderança como a capacidade de motivar as pessoas para segui-las e cita essa definição como uma característica comum as mulheres que são consideradas boas líderes, ou seja, demonstra que a capacidade de motivar das mulheres é um grande diferencial para o papel do líder na atualidade.

Botelho (2008, p. 120) nos fala "que as mulheres trazem contribuições significativas para o novo modelo de paradigma organizacional, um modelo baseado no conhecimento humano". Neste novo contexto de liderança, vem se valorizando características como flexibilidade, intuição, sensibilidade, capacidade de trabalhar em equipe e administrar as diversidades que são atributos mais direcionados ao sexo feminino. Botelho (2008) complementa dizendo que a carreira pessoal e profissional das mulheres vem sendo marcada pela presença da superação de desafios e barreiras, e também pela extrema força de vontade de vencer e alcançar os objetivos por elas estipulados.

Dessa forma, antes de serem vistas como mulheres, querem e precisam ser contempladas como executivas e profissionais de respeito, reconhecidas 
por suas capacidades técnicas e gerencias. E ainda "que ser mulher e executiva é desfrutar de um status que poucas já atingiram" (BOTELHO, 2008, p.120).

Segundo Grzybovski et al. (2002), as mulheres atuam com uma liderança mais participativa, encorajadora e acolhedora. Por estas características típicas do comportamento empreendedor feminino a mulher consegue alcançar resultados e ganha espaço e reconhecimento através da sua administração.

O estilo de liderança desenvolvido pelas mulheres ressalta o enfoque nas pessoas e não nas tarefas, demonstrando grande habilidade ao lidar com os recursos humanos que disponibiliza (MACHADO, 1999).

Esses comportamentos se configuram cada vez mais nas organizações, empreendimentos ou até empresas geridas por mulheres, poderíamos chamar de modelo "feminino de gerir".

De acordo com uma pesquisa realizada pela consultoria americana Zenger Folkman, as mulheres são boas líderes pois formam equipes melhores, são mais respeitadas e possuem a capacidade de avaliar com clareza os recursos necessários para atingir uma meta. As habilidades de liderança como cooperação, comunicação e compartilhamento, são facilmente associadas às mulheres. (REVISTA PEGN, 2014). Sendo assim o papel da mulher na liderança se destaca também no empreendedorismo.

As mulheres encorajam a participação, a partilha do poder e da informação e tentam aumentar a autoestima dos seguidores. Preferem liderar pela inclusão e recorrem a seu carisma, experiência, contatos e habilidades interpessoais para influenciar os outros.

Segundo Eagly et al (2003), normalmente o estilo de gestão adotado pelas mulheres é transformacional, enquanto os homens utilizam um estilo mais transacional. O estilo transformacional está relacionado à capacidade de um líder de influenciar valores, atitudes, crenças e comportamentos dos membros de sua equipe, a fim de cumprir a missão e os objetivos da organização, ou seja, os líderes transformacionais tentam fazer mudanças que aumentam a eficiência e desempenho organizacional (Latest, 2010). Já a liderança transacional compreende uma simples troca entre líderes e seguidores no qual o primeiro oferece recompensas na forma de prestígio ou dinheiro pela obediência aos seus desejos. Dessa forma as mulheres exerceriam uma liderança baseada no carisma e na inspiração o que estaria positivamente relacionado com melhores desempenhos dos subordinados 
(Bryman, 2004). 


\section{Métodos e procedimentos de coleta e de análise de dados do estudo}

\subsection{Estratégia de investigação}

Este trabalho trata-se de um estudo de caso de natureza qualitativa exploratória e descritiva.

A pesquisa exploratória é a ferramenta ideal para descobrir novas ideias ou dados referentes ao tema estudado (ZIKMUND e BABIN, 2011). Segundo Gil (2008), a utilização da pesquisa exploratória permite que se consiga novas informações a respeito do tema abordado, esclarecendo conceitos para que questões ou hipóteses bem definidas sejam abordadas em outras etapas ou estudos.

Na concepção de Gil (1999), a pesquisa descritiva tem como principal objetivo descrever a característica de determinada população ou fenômeno, de forma a identificar, relatar e comparar.

Tal estratégia permitiu identificar e caracterizar o perfil empreendedor das mulheres que se associam à Lídera, questões de liderança pela perspectiva das associadas, seus desafios e a contribuição da entidade no desenvolvimento dos empreendimentos através dos diversos serviços oferecidos.

\subsection{Procedimentos e instrumentos de coleta de dados}

As informações e dados relevantes para esta pesquisa foram coletados a partir de fontes primárias e secundárias.

Para a realização do referencial teórico foram consultados livros, artigos, teses de doutorado, relatórios do GEM e reportagens. Todas essas pesquisas bibliográficas foram importantes para o maior aprofundamento sobre o tema em questão como também contribuiu para a elaboração do roteiro de entrevistas feitas durante a fase de pesquisa de campo. Também como fontes secundárias e importantes, principalmente para a análise dos estudos de caso, foram os documentos institucionais e sites na internet da Lídera.

O estágio do campo de pesquisa foi constituído a partir da aplicação de um questionário no google forms e de entrevistas com as associadas da 
Lídera, e dois procedimentos base foram usados para a coleta, um questionário misto e um roteiro de entrevistas.

Inicialmente aplicou-se o questionário misto, ou seja, constituído de questões abertas, fechadas e algumas questões que dependiam de respostas dadas a outras perguntas, denominadas "dependentes" (GIL, 1999; MARCONI; LAKATOS, 1996).

Como fontes primárias foram realizadas entrevistas semiestruturadas com mulheres fundadoras da Lídera, conforme indicação da Diretora de Pesquisa. As entrevistas foram realizadas no período de setembro de 2018 a outubro de 2018, e dirigido em torno de um roteiro de entrevista (Anexo I) com duração média de trinta minutos com as empreendedoras associadas a Lídera.

Cabe ressaltar que devido à localização geográfica das respondentes da associação e o prazo curto de tempo, as entrevistas foram efetuadas por telefone ou chamada de voz via WhatsApp e não de forma presencial. Ao todo 29 mulheres associadas responderam ao questionário online e 9 delas participaram da entrevista por meio eletrônico.

Tanto o questionário online quanto as entrevistas foram estruturadas de forma a permitir que fossem analisadas as características dessas empreendedoras, se realizaram algum planejamento para a iniciação do negócio, razões para serem associadas a Lídera, desafios enfrentados ao abrir o negócio e noções de liderança.

Dessa forma, objetivou-se nas entrevistas que os participantes discorressem livremente sobre seus pensamentos, tendências e reflexões acerca dos temas estudados (VIRGILLITO, 2010).

\subsection{Formas de tratamento e análise dos dados coletados}

O tratamento de dados foi realizado por meio da análise das respostas dos questionários e da análise das respostas obtidas nas entrevistas semiestruturadas que foram gravadas e transcritas, ambos respondidos pelas integrantes comitê da Lídera. Através das informações contidas no material coletado, foi feito um compilado com as partes mais significativas relacionando-as com os temas do referencial teórico tendo como finalidade alcançar o objetivo do estudo.

Foram analisados os dados referentes ao perfil empreendedor das 
associadas, suas características e desafios encontrados no processo de abertura do próprio negócio. Em seguida, foi abordada a questão da liderança a fim de identificar a existência da mesma, a influência e comportamentos específicos no ambiente dos negócios.

\subsection{Limitações do Estudo}

Ao longo do processo de pesquisa, algumas limitações foram identificadas.

Levando em conta o fato de ser uma pesquisa de natureza qualitativa exploratória, foram priorizadas as entrevistas com as fundadoras e que hoje lideram as iniciativas da associação, pois o objetivo foi conhecer o perfil empreendedor das mesmas.

Além disso, houve uma complexidade na etapa de agendamento das entrevistas por parte das integrantes da Lídera, pois muitas apresentaram problemas em relação a disponibilidade de dia e horário, naturalmente compreendido pois tratam-se de empreendedoras e muitas delas em dupla jornada (empreendedoras e mães).

Com isso, algumas gravações ficaram com qualidade inferior às outras devido à baixa frequência de sinal da telefonia e internet. $O$ fato das entrevistas não serem efetuadas pessoalmente, implica em respostas rápidas, menos duradouras, o que pode ter impactado em um grau inferior de riqueza de detalhes. 


\section{4 . Apresentação e análise dos resultados}

\subsection{Lídera}

A Lídera é uma associação sem fins lucrativos, localizada na região de Passo Fundo no Rio Grande do Sul, organizada de forma a promover parcerias, negócios e ações em prol do desenvolvimento da cultura do empreendedorismo e da liderança feminina. A associação é regida a partir de um estatuto, suas normas de conduta respaldam o posicionamento de realizar um projeto sustentável e responsável.

O grupo que inicialmente foi denominado Confraria, transformou-se em um movimento organizado, que se estruturou para formar uma associação com objetivo de oportunizar mais do que momentos de lazer e diversão para suas associadas, mas também proporcionar vivências de aprendizado e desenvolvimento para suas integrantes e comunidade. (SITE LÍDERA, 2018)

A missão da Lídera é promover um ambiente de evolução e desenvolvimento de mulheres, focado no empreendedorismo, liderança e inovação. Os valores da Lídera destacam sua atuação como associação na cidade de Passo Fundo. Seus valores são: respeito, foco, determinação, união, diversidade de ideias, maturidade, conhecimento, organização, liderança, responsabilidade, competência, comprometimento, positividade. (SITE LÍDERA, 2018)

A Lídera possui cindo objetivos estratégicos declarados, que são:

1. Criar um ecossistema sustentável para amparar as ações associação.

2. Ter a marca reconhecida e valorizada, através da credibilidade das ações e projetos junto à sociedade.

3. Despertar e desenvolver nas mulheres suas potencialidades de liderança e de empreendedorismo.

4. Fomentar uma rede de negócios entre mulheres empreendedoras.

5. Incentivar lideranças femininas da comunidade para atuarem como agentes de transformação.

A marca "LÍDERA - Associação de Mulheres Empreendedoras" foi pensada com base nos conceitos de branding, que embasam 0 posicionamento e proposta de valor, definindo os objetivos da comunicação e direcionando suas ações. 
A associação possui como base três principais pilares, (SITE LÍDERA, 2018):

- Empreendedorismos e negócios: Visa estimular e oportunizar o desenvolvimento de habilidades e competências, para o fortalecimento da atuação feminina em áreas como o empreendedorismo na carreira, negócios e inovação.

- Bem-estar: Busca atender diferentes anseios e necessidades disponibilizando/compartilhado conteúdos que promovam: autoconhecimento, espiritualidade, alimentação saudável, gestão de carreira/tempo, diversão, sedução, marketing pessoal.

- Social: Especialmente na condução deste pilar, o objetivo não é criar algo novo, mas aliar o conhecimento e expertise da associação aos projetos que já estão pautados como necessários às comunidades do entorno.

A dinâmica de atuação da Lídera consiste em utilizar a expertise das associadas para promover ações de socialização destas experiências, oportunizando conhecimento, motivação, promoção, capacitação e fortalecimento coletivo das estratégias sociais, prioritariamente dirigidos a mulheres expostas a vulnerabilidades, incluindo a financeira, visando à autonomia econômica, oportunidades em um contexto geral e equidade a todas às mulheres.

A Lídera possui dois principais projetos (SITE LÍDERA, 2018):

- Mulheres em ação: em parceria com o Ministério Público, busca construir a inclusão da mulher em uma oportunidade de empreender, tirandoas do desemprego, da situação de dependência financeira, ampliando possibilidades de renda principal ou extra às famílias, culminando na autoestima e na capacidade de produzir o próprio sustento.

- Cuidar de quem cuida: promover a participação de um grande número de mulheres em encontros conduzidos por equipes técnicas, que buscam desenvolver as habilidades necessárias para o atendimento qualificado dos serviços voltados a famílias em situação de vulnerabilidade.

\subsubsection{Idade e Nível de Escolaridade}

Segundo a Rede de Mulher Empreendedora, as empreendedoras brasileiras têm em média 39 anos e mais da metade 55\% têm filhos. Dessas que já são mães, $75 \%$ dizem que decidiram empreender depois da maternidade. A idade média das mulheres da Lídera é de 36 anos e foi 
identificada através da pesquisa realizada. De acordo com o questionário, $44 \%$ das empreendedoras da Lídera não possuem filhos.

Segundo dados do (GEM RS 2016) abordado no capítulo 2 deste trabalho, a faixa etária com maior representatividade, 35\% é entre 25 e 34 anos para os empreendedores iniciais (TEA). Para os empreendedores estabelecidos (TEE), as idades a faixa de idade que mais prevalece é de 45 a 54 anos, equivalente a $31,9 \%$. Portanto com os resultados da pesquisa e comparação a teoria, pode-se dizer que as mulheres da Lídera estão dentro da faixa etária dos empreendedores no âmbito nacional. No quesito regional, elas estão abaixo da faixa etária no que se diz respeito a empreendedores estabelecidos. Abaixo os gráficos com os resultados da pesquisa.

\section{Gráfico 6: Idade das Empreendedoras Líderas}

\section{Idade das empreendedoras Lídera}

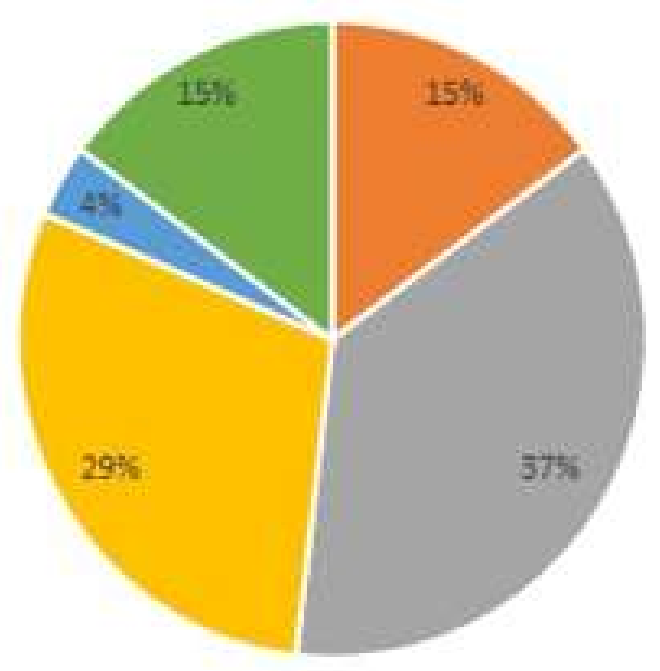

- IDADE $=21-30=31-40=41-50=51-60=$ näo informaram a idade Fonte: Dados da Pesquisa (2018) 


\section{Possuem filhos?}

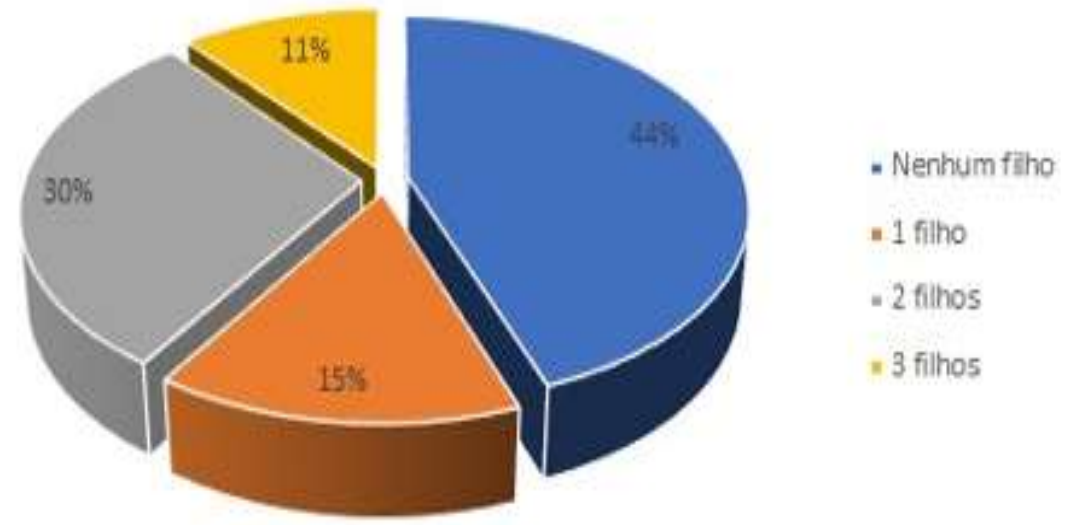

Fonte: Dados da Pesquisa (2018)

No âmbito educacional, foi abordado no referencial teórico de acordo com os dados do (GEM RS 2016) o nível de escolaridade, pois é altamente importante para a criação e fortalecimento de empreendimentos. Logo, esse aspecto se confirmou nas mulheres integrantes da Lídera $86,2 \%$, tem alta escolaridade, conforme Gráfico 8 abaixo. Esse resultado pode ser comparado também com os perfis das empreendedoras brasileiras, de acordo com a Rede de Mulher Empreendedora (2017), onde quase 80\% têm ensino superior completo ou mais.

Gráfico 8: Escolaridade das empreendedoras Líderas

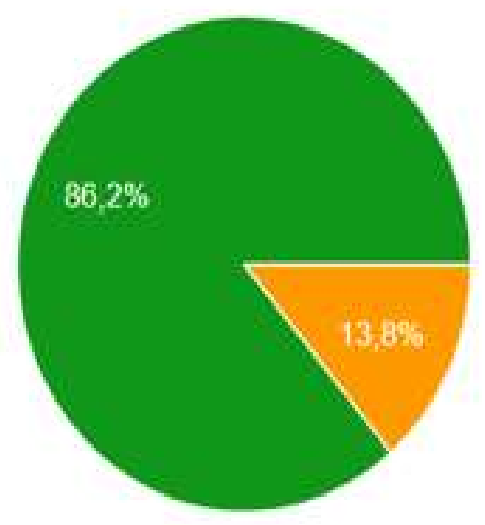

Ensino Fundamental

Ensino Médio

Graduaçāo

Especializaçăo elou mestrado efou doutorado

Fonte: Dados da Pesquisa (2018) 
Gráfico 9: Profissão das empreendedoras Líderas

Profissão das empreendedoras Lídera

Empresár ia

- Analista de Sistemas

- Consuitora

- Arquiteta Urbanista

- Professora / instrutura treinamentos

- Psicóloga / Pedagoga / Coach

- Administradora de Empresas/Gestora de RH / Assistente de Administração/Ger ente de Relacionamento

- Cirurgia dertista

- Enfermera

- Cosmetologa

- Jornalista

Fonte: Dados da pesquisa (2018)

O Gráfico 10 abaixo tem os percentuais das mulheres em relação ao estado cível. A grande maioria das associadas com $41 \%$ é casada. Esse quantitativo ressalta a teoria de (JONATHAN, 2011), de que administrar a casa e cuidar da família são algumas das múltiplas atividades que as empreendedoras conciliam nas suas rotinas.

Cabe aqui destacar que existe uma parcela das empreendedoras da Lídera equivalente a $22 \%$ que são solteiras, levando a crer que cresce a busca pela estabilidade profissional e financeira por parte dessas mulheres antes mesmo de iniciarem uma vida conjugal. 
Gráfico 10: Estado cível das empreendedoras Lídera

\section{Estado Civil das mulheres Lidera}

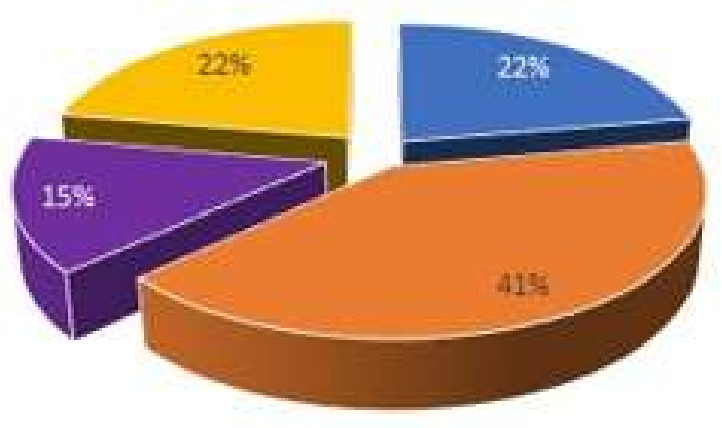

- Soltera - Casada - Divorclada - Uniäo esável

Fonte: Dados da pesquisa (2018)

\subsection{Motivos das Associadas para Empreenderem}

Foi perguntado para as empreendedoras quais as diversas razões para começar a empreender, podendo escolher mais de uma resposta. Portanto $58,6 \%$ responderam que identificaram uma oportunidade de mercado. A flexibilidade de horário foi escolhida logo em seguida na ordem com representatividade de $51,7 \%$. Um percentual de $48,3 \%$ refere-se ao desejo de trabalhar com o que gosta. A busca por uma renda melhor foi considerada por $44,8 \%$ como motivação. Outro fator que foi considerado por $17,2 \%$ delas foi a possibilidade de trabalhar de casa. $27,6 \%$ entendem que empreender é a realização de um sonho. Ter mais tempo para filhos e família foi considerado por $17,2 \%$ das associadas. Por fim, 3,4\% escolheram a opção de não possuírem um motivo para empreender. Conforme o Gráfico 11 abaixo: 
Gráfico 11: Motivos para empreender das empreendedoras Lídera

MOTIVOS PARA EMPREENDER

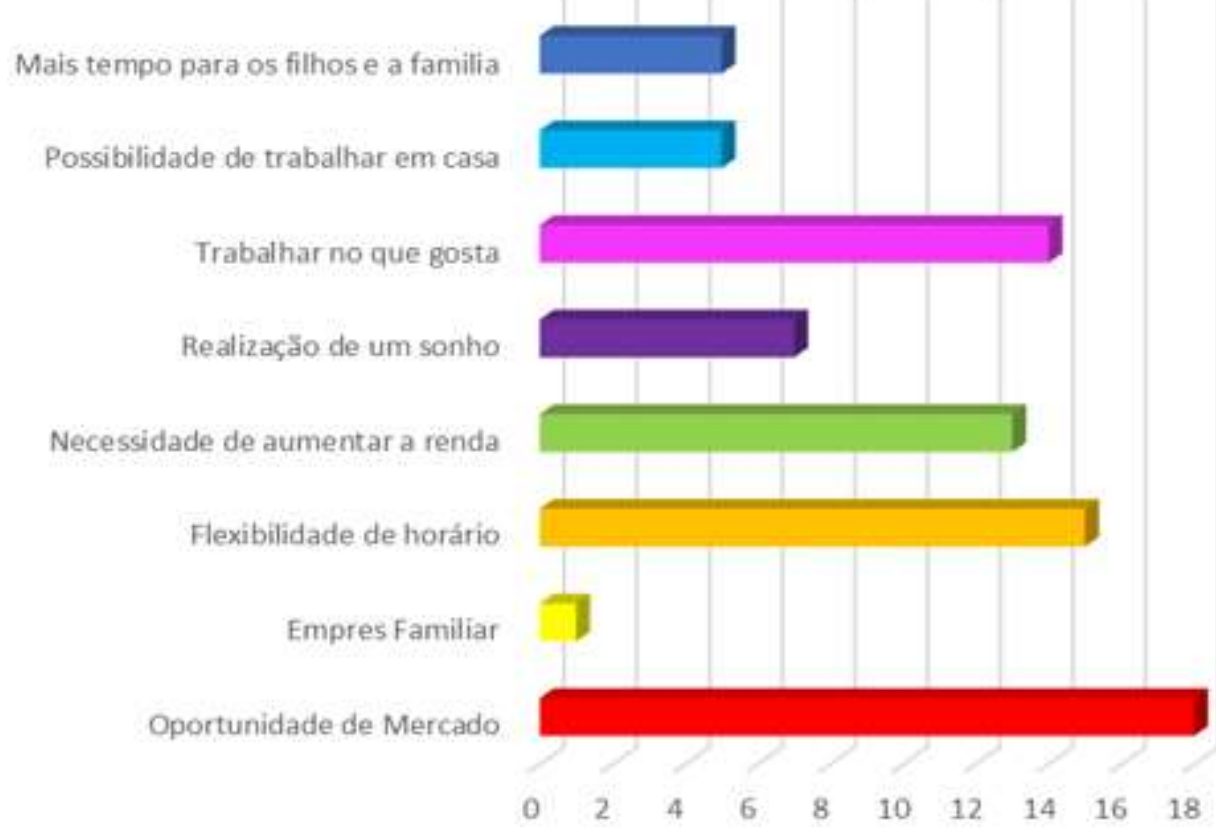

Fonte: Dados da pesquisa (2018)

Como abordado no tópico de empreendedorismo feminino no capítulo 2 , o alto percentual obtido na pesquisa no âmbito da motivação a empreender, confirmam as informações do relatório do GEM RS 2016 onde 66,7\% representa a abertura do empreendedorismo por oportunidade.

Outro ponto que se comprova com a teoria abordada, segundo Gomes \& Santana (2009), é a motivação para empreender pela questão da flexibilidade de horários, muitas entrevistadas apontaram esse fator como justificativa, logo compreendem que podem compatibilizar o trabalho e a família.

Boa parte das entrevistas apontaram a busca pela melhoria da renda como fator motivador, confirmando os resultados da Pesquisa Nacional por Amostra de Domicílios (PNAD, 2016), que aponta que a principal fonte de renda no orçamento familiar se dá por meio dos resultados de seus empreendimentos. Logo esses, são responsáveis pelo sustento de quatro em cada dez lares brasileiros que são chefiados por mulheres.

\subsubsection{Elaboração do Plano de Negócio}

No capítulo 2 deste trabalho foi abordada a questão da elaboração de 
um plano de negócio, que de acordo com Dornelas (2000) é definido como um plano geralmente usado para descrever minuciosamente o negócio, identificar os riscos e propor planos para minimizá-los e até mesmo evitá-los; identificar seus pontos fortes e fracos em relação concorrência e o ambiente de negócio em que você atua; conhecer seu mercado e definir estratégias de marketing para seus produtos e serviços; analisar o desempenho financeiro de seu negócio, avaliar investimentos, retorno sobre o capital investido; enfim, você terá um poderoso guia que norteará todas as ações de sua empresa. (DORNELAS, 2000, p. 05).

Comparando a teoria acima com os resultados da pesquisa (Gráfico 12), onde foi possível identificar que mais da metade das mulheres $56 \%$; realizaram um planejamento para a abertura do empreendimento. Isso demonstra que possuem um cuidado para minimizar as chances de riscos e uma preocupação com a trajetória do negócio. Porém é também considerada alta a parcela das associadas que não definiram um plano de negócio $18 \%$ ou que realizaram o mesmo apenas mentalmente 19\%, podendo esse ser um fator problemático para a solidificação do negócio.

Gráfico 12: Planejamento para abertura do negócio pelas empreendedoras Lídera

\section{PLANEIAMENTO PARA ABERTURA DO NEGÓCIO}
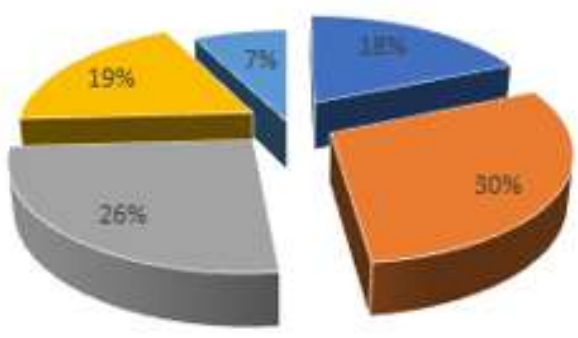

- Nenhum

- Sim, Plano de Negócios

" Sim, planejamento por meio de um consultor

- Sim, planejamento mental

- Negócio inciado por outra pessoa

Fonte: Dados da pesquisa (2018)

\subsubsection{Fonte de recursos utilizada pelas Associadas para abertura do negócio}

Buscou identificar a origem do recurso econômico utilizado pelas "líderas" para abrir os negócios. De acordo com (Hisrich; Peter; Shepherd, 2009), o gênero feminino recorre à seus bens e suas economias para criarem 
seus empreendimentos, logo isso de confirma por meio das respostas de $65,5 \%$ das entrevistadas.

Os mesmos autores defendem que as mulheres encontram mais dificuldades para conseguir financiamento junto a banco e investidores. $O$ baixo percentual $3,4 \%$ do apoio de investidores às mulheres entrevistadas comprovam tais fatos. Abaixo Gráfico 13 dos dados sobre recurso usado.

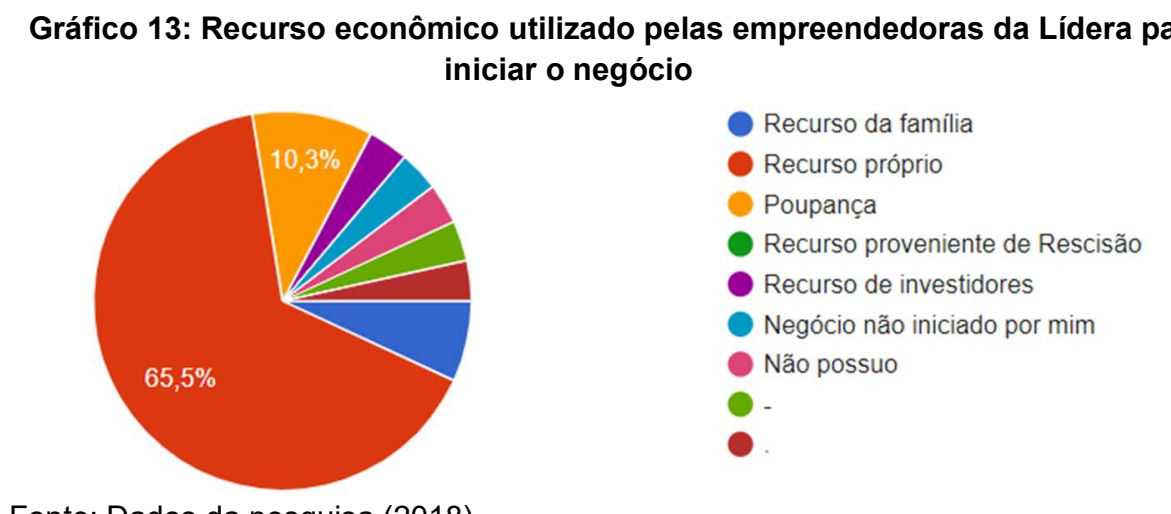

Fonte: Dados da pesquisa (2018)

A associada da Lídera, A.P.B. ainda comentou sobre essa dificuldade ao ser questionada sobre os desafios que enfrentou para abrir sua empresa.

"Do meu pai eu já tive apoio financeiro em termos de dinheiro mesmo, porque a gente é um MEl e não temos apoio do Governo. A gente precisou comprar um carro para trabalhar para a empresa efetivamente, não conseguimos financiamento, em nenhum banco, por ser MEl e por seu uma empresa nova. Então no início eu tive o apoio do meu pai quando ele me emprestou o dinheiro para comprar o carro". (A.P.B. Associada à Lídera)

\subsubsection{Características dos negócios empreendidos pelas associadas à Lídera}

A pesquisa procurou levantar informações por meio do questionário sobre o porte e faturamento das empresas associadas à Lídera de acordo com a lei geral da MPE's e do BNDES. O Gráfico 14 abaixo aponta que mais da metade dos empreendimentos $59,1 \%$ são microempresas e possuem um faturamento anual igual ou inferior a $\mathrm{R} \$ 360 \mathrm{mil}$. 
Gráfico 14: Porte da empresa de acordo com a Lei Geral das MPE's e BNDS e Faturamento

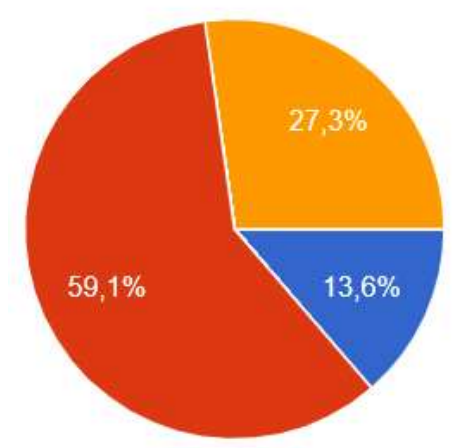

Fonte: Dados da pesquisa (2018)
MEI - Micro Empreendedor Individual

Microempresa - Faturamento anual igual ou inferior a R\$ 360 mil

Pequeno Porte - Faturamento anual entre $\mathrm{R} \$ 360$, mil a R\$ 4,8 milhões

- Média - Faturamento anual maior que R $\$ 4,8$ milhões e menor ou igual a RS 300 milhões

Grande - Faturamento maior que RS 300 milhões

Foi perguntado no questionário os temas mais relevantes para empreendedoras em fase de planejamento do negócio, podendo as respondentes escolher múltiplas opções. Os temais mais relevantes apontados pelas entrevistadas foram planejamento estratégico, marketing e comunicação, e formação de preços. Portanto isso demonstra a importância de uma rede de apoio onde as mulheres possam ter acesso a inúmeros serviços e suporte para iniciar ou fortalecer seu empreendimento, conforme Gráfico 15 abaixo.

Gráfico 15: Temas mais relevantes para as empreendedoras da Lídera em fase de planejamento

\section{TEMAS MAIS RELEVANTES PARA AS EMPREENDEDORAS LÍDERA COM NEGÓCIOS EM FASE DE PLANEJAMENTO}

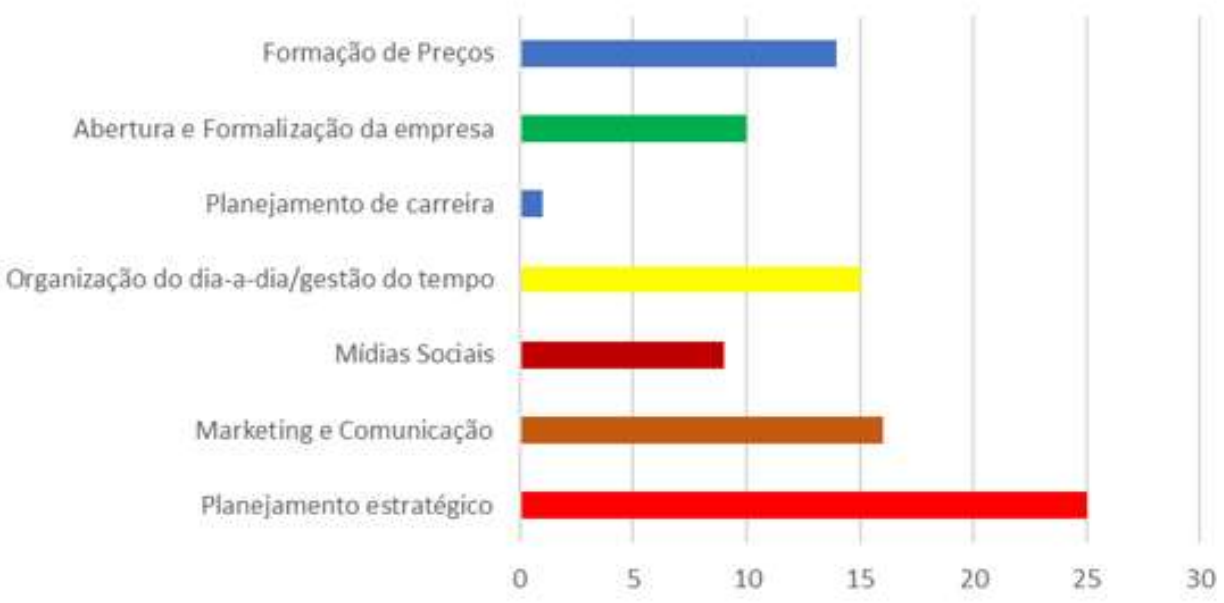

Fonte: Dados da pesquisa 2018 


\title{
4.2.4 Dificuldades enfrentadas pelas empreendedoras da Lídera ao abrirem o negócio
}

As mulheres que estão empreendendo precisam vencer inúmeros obstáculos e desafios. No capítulo 2 foi citado o estudo feito pelo Sebrae e pelo IBPQ (GEM 2016), o qual o identificou que as empreendedoras sofrem preconceito de gênero; menor credibilidade; pois hoje exercem funções que anteriormente erem executadas majoritariamente por homens.

No relato da consultora associada, G.R, essa teoria se faz presente.

\begin{abstract}
"Com relação a ser mulher, por se jovem eu percebi que a aparência física as vezes as pessoas duvidam do seu potencial, pelo fato de ser novinha, mais jovem, sou pequena e desde o porte físico. Eu notava que ao final do atendimento, o cliente no início começava desconfiado, mas no final ele dizia que foi muito bacana a consultoria e o trabalho. E no início quando você chegou aqui a gente não te conhecia direito, mas você realmente sabe. Então dava para perceber nas entrelinhas que tinha uma desconfiança inicial, por que as vezes tem essa coisa de que consultor é uma pessoa mais experiente e mais velha, cabeça branca, é essa a imagem que as pessoas têm do consultor, principalmente do homem né, se ele não for careca e grisalho ele não sabe". (G.R. Associada à Lídera)
\end{abstract}

Na experiência na R.M, também consultora, o preconceito ao gênero é ainda mais latente, porém não a impediu de buscar uma posição sólida no mercado:

"Eu tive um pouco no início, de preconceito por parte de homens que trabalha nessa área de consultoria e são bem mais velhos. Tive declaradamente pessoas falando que eu não conseguiria porque eu era uma menina jovem querendo entrar no lugar de homens que estavam com ali há 40/50 anos na profissão. Eu tive um pouco disso, mas isso não acabou me impedindo de seguir em frente". (R.M. Associada à Lídera)

Os principais fatores limitantes para abertura e manutenção de novos negócios segundo os empreendedores do Rio Grande do Sul, são acesso a recurso financeiros através de empréstimos e financiamentos $42,4 \%$ e a legislação e impostos em segundo lugar com 37,5\%. (GEM RS 2016)

Essa limitação foi relatada pela empresária F.V. que ao ser questionada, apontou a questão burocrática como a maior dificuldade para abriu seu negócio:

"A questão burocrática principalmente né. Eu acho que o Brasil infelizmente é um país que desestimula o empreendedorismo. Nós temos uma população que é muito criativa e empreendedora só que tem muita informalidade ainda justamente por causas das dificuldades burocráticas, de legislação. O tempo é muito complicado para formalizar e fazer tudo direitinho. Então eu acho que o principal empasse foi o burocrático e sem contar o custo dessa burocracia né, que acaba se torando elevadíssima, todo mundo leva uma fatia do seu 
investimento né". (F.V. Associada à Lídera)

\subsubsection{Rede de apoio e temas relevante para o empreendimento pela visão das Associadas}

No âmbito dos apoios reconhecidos como relevantes, segundo HISRICH; PETERS; SHEPHERD (2009), as mulheres costumam mencionar primeiramente seu cônjuge e amigos íntimos. Elas também contam com outras fontes de apoio e informação, como grupos profissionais femininos e associações comerciais.

No caso das empreendedoras da Lídera a teoria pode ser confirmada pois a maioria das respostas das mulheres entrevistadas responderam receber incentivo da família para criar e manter o empreendimento, como mostra Gráfico 16 abaixo:

Gráfico 16: Apoios relevantes para a ação empreendedora feminina de acordo com as empreendedoras da Lídera

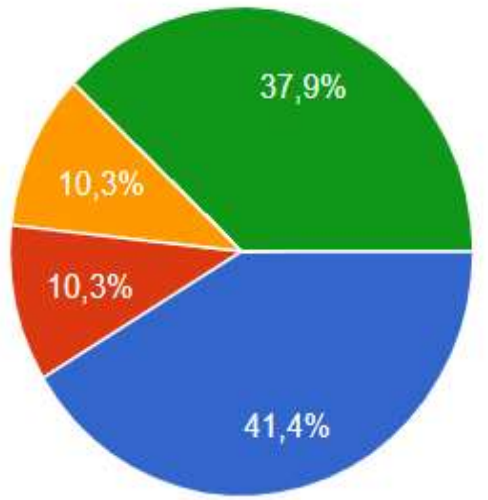

Possui incentivo da família para abrir/ cuidar do negócio

Sente-se sobrecarregada com as responsabilidades do negócio e da casa

Sente-se muito sobrecarregada

Possui sócios que ajudam a gerenciar o negócio

Fonte: Dados da pesquisa (2018)

Através da plataforma de apoio Rede Mulher Empreendedora, as mulheres conseguem ter acesso a uma imensa gama de suporte necessário para a criação a estruturação do seu negócio como sites com conteúdo relevantes e de qualidade, eventos de networking, cursos, mentorias, parcerias com empresas que acreditam na causa do empreendedorismo feminino para levar oportunidades e facilidades para as mulheres; espaço publicitário em destaque no site, por meio de marketplace; indicações para fomentar o comércio entre pequenas mulheres donas de negócio.

No Gráfico 17 abaixo, obtido com dados do questionário, é possível identificar que tipo de apoio as associadas da Lídera julgam necessários e relevantes para seus negócios. Logo, é possível observar a importância de uma rede de apoio a empreendimentos femininos, tendo em vista que as 
associadas selecionaram a maioria pelo menos seis temas.

Gráfico 17: Temas mais relevantes para as empreendedoras da Lídera e seus negócios

\section{TEMAS MAIS RELEVANTES PARA AS EMPREENDEDORAS LÍDERA E SEUS NEGÓCIO}

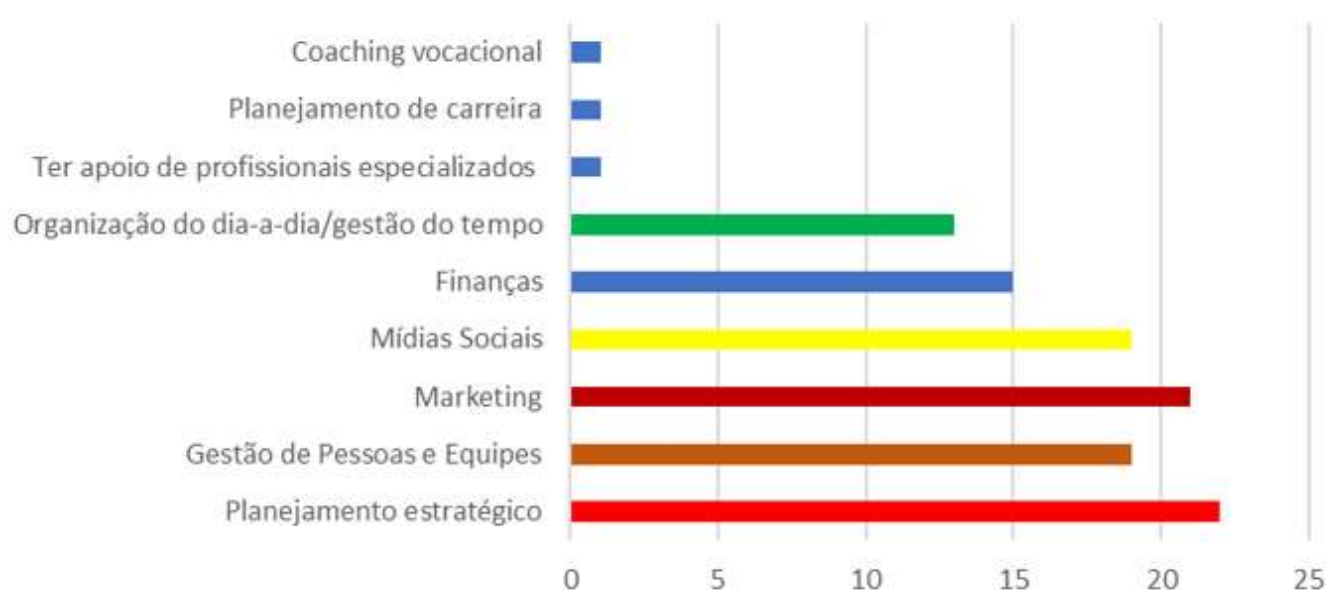

Fonte: Dados da pesquisa (2018)

\subsubsection{Percepção das Associadas sobre faturamento pessoal e participação da renda no orçamento familiar}

Conforme as informações da Pesquisa Nacional por Amostra de Domicílios (PNAD, 2016) citada no capítulo 2 na sessão do perfil empreendedor feminino e desafios, foi constatado que a mulher passou a ser importante colaboradora, ou até mesmo a principal fonte de renda no orçamento familiar por meio dos resultados de seus empreendimentos.

Com os resultados das entrevistas sobre a renda pessoal do faturamento anual do negócio, o Gráfico 18 abaixo demonstra que 40,9\%, conseguem obter uma renda mensal na média pagas por muitas empresas. Isso mostra que as mulheres estão aumento a participação, porém deu uma forma ainda lenta em relação a empreendimentos abertos pelo gênero masculino. 
Gráfico 18: Renda pessoal do faturamento anual do negócio das empreendedoras da Lídera

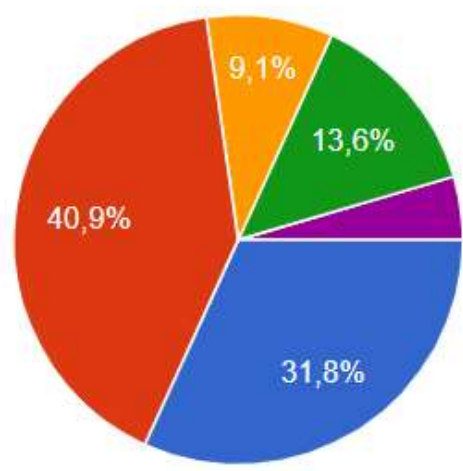

Fonte: Dados da Pesquisa (2018)
Não faço ideia

Entre R\$12 mil à R\$ 35 mil (média entre 1 a 3 salários mês)

Mais que R\$ 35 mil e menos ou igual a R\$ 58 mil (média acima de 3 e até 5 salários mês)

Mais que RS 58 mil e menos ou igual a R\$ 115 mil (média acima de 5 e a..

Mais que R\$ 115 mil (média acima de 10 salários mês)

A associada A.P. quando perguntada sobre a questão da renda em relação ao gênero e sobre a sua partição na renda familiar depois de criar o empreendimento esclareceu:

"Diminuiu. Enquanto eu trabalhava na empresa, cuidava da empresa e também era professora e analista. O salário vinha desse emprego formal. A empresa começou a dar lucro e efetivamente sobrar dinheiro a partir desse ano. Eu tive que parar a empresa por dois anos por causa do meu bebê. Aí acabei não trabalhando pois me dediquei ao meu filho. Mantive apenas os contratos que já tinha. Não pude trabalhar com afinco. Apesar da crise a empresa conseguiu se manter, porque não tínhamos dividas e não foi preciso fechar a empresa. Esse ano a empresa está conseguindo girar e dar lucro. Mas a contribuição é bem menor esse ano, pois temos que pagar o carro. Praticamente quem está mantendo a casa é o meu marido". (A.P. Associada à Lídera)

Isso se comprova também com a fala da fundadora da Lídera., ao ser questionada sobre a sua participação na renda da família após a abertura do negócio. Segundo ela:

"No início eu diminui porque eu precisei investir na empresa, e até pedi empréstimos. Ainda estou nessa fase porque meu negócio foi criado há pouco tempo. Então eu estou ainda mais investindo do que tirando da empresa. Agora no início é um processo que ainda não aumentou a minha renda, mas vai aumentar". (M.C. Fundadora da Lídera)

$\mathrm{Na}$ concepção da associada F.M. sobre a contribuição da renda: "aumentou, isso foi um dos motivos que me fez mudar de área e empreender". Para a empreendedora R.M. a renda aumentou depois que resolveu abrir um negócio e ainda faz uma comparação ao salário do trabalho anterior e sobre a contribuição do marido:

"Aumentou consideravelmente, apesar de que no meu último trabalho eu tinha um bom salário. Hoje contribuo bastante, as vezes equivalente ou até 
mais do que o meu marido ganha. E é muito variável, tem mês que não entra muito bem. Não conto como uma renda mensal e sim como algo anual". (R.M. Associada à Lídera)

Portanto, vale ressaltar que, um grande número das empreendedoras associadas $31,8 \%$, não possui conhecimento sobre quanto sobra para elas do faturamento anual do negócio. A fundadora da associação M.C. confirma em sua resposta dizendo que possui dificuldade no planejamento financeiro, " a principal dificuldade foi colocar em pratica a questão da organização e conhecimento financeiro".

\subsubsection{Características Empreendedoras pelas entrevistadas}

Dornelas (2003) define que o empreendedor de sucesso possui características extras, algumas delas são: indivíduos que possuem uma visão a longo prazo do negócio, sabem agregar valor aos serviços e produtos que ajudam a colocar no mercado; sabem explorar ao máximo as oportunidades, é um indivíduo curioso e atento a informações; são determinados e dinâmicos, atropelam as adversidades, "faz acontecer, são bem relacionados (networking), sabem construir uma rede de contatos; são organizados e assumem riscos calculados".

Para empreendedora F.V., a principal característica é assumir riscos ao ser questionado sobre o perfil do empreendedor:

(...) eu acho que é arriscar mesmo. Quando você começa, você nunca tem certeza de nada. O risco que você muitas vezes tentar calcular, mas muitas vezes você não tem noção do que vai acontecer no caminho. Você tem que ter um senso, ser corajoso mesmo, tem que arriscar, porque se você não arriscar, você não vai chegar a lugar nenhum. (F.V. associada Lídera)

A associada ainda F.V. ainda aponta a importância do empreendedor para a sociedade: "acho que é uma obrigação de nós como seres humanos mesmo, procurar deixar alguma marca na sociedade, melhorar alguma coisa. O trabalho que a gente gera acaba sendo importante no sustento de outras famílias direto ou indiretamente". Confirmando assim o que Dornelas (2005) ressaltou como sendo um dos comportamentos e características de empreendedores: criação de valor para a sociedade.

Na percepção da empresária N.L., a liderança é uma atitude de um empreendedor de sucesso: "a maior delas é a liderança, eu acredito que é a maior e principal característica. Eu acredito que é possível desenvolver a liderança". E ainda destaca: "acho também que tem que ter uma inteligência emocional bastante desenvolvida também, resiliência, foco, determinação e 
não ter medo de arriscar".

Conforme defendido por WEVER e BRITTO (2003) que cita cinco elementos das características do empreendedor sobre a percepção de oportunidade: a criatividade e inovação, habilidade ao aplicar esta criatividade, força de vontade e fé, foco na geração de valor e correr riscos. A associada M.B.D., considera o foco como uma característica bastante importante e destaca:

"Acho que um empreendedor de sucesso não basta ter só ideias inovadoras, ter conhecimento, ele precisa saber fazer. Tem gente que tem muitas ideias, mas na hora de realizar não consegue concretizar. O perfil de empreendedor é aquele que consegue enxergar, baixar uma estratégia e conseguir operar ela. As vezes ideias a gente tem um monte, mas na hora de botar o negócio mesmo e fazer para operar, aí começa a aparecer as dificuldades. Então para mim o bom empreendedor é aquele que olha tanto a operação quanto a estratégia, e ajuda a desenvolver o negócio. Quer dizer, não temer e ter ousadia". (M.B.D., Associada à Lídera)

Como dissertado por MORI (1998) no referencial teórico desse estudo, os empreendedores são definidos como indivíduos que inovam, identificam e criam oportunidades de negócios, montam e coordenam novas combinações de recursos. Ao ser questionada sobre sua percepção das características de empreendedoras de sucesso, a administradora de empresa M.B. disserta:

(...)você precisa de muita disciplina, que é uma das atitudes, muita disciplina, conhecimento e um bom relacionamento. É preciso estar atento hoje mais do que nunca, as mudanças de mercado, se adaptar rapidamente, ter essa possibilidade de mudar rápido para atender o mercado. Qualquer negócio hoje, hoje você pode estar assim, mas amanhã já tem um outro cenário. Pois são muito os entrantes, as vezes não é um entrante direto do teu seguimento, mas de uma outra forma. (...), também precisa se diferenciar, ter atitudes, ter dedicação e disciplina e planejamento. (M.B. Associada à Lídera)

A perspectiva da associada G.R.C., um empreendedor " tem que ter muita criatividade, principalmente para atrair o cliente. Precisa também ser inovador. Nem todos assumem riscos, eu mesma fiquei travada diante de alguns desafios. Superar obstáculos para crescer economicamente". Tal fala pode ser relacionada com as terias citadas no tópico do perfil empreendedor feminino. G.R.C., ainda completa:

"Tem que ser dinâmico para fazer a coisa acontecer, porque você é dono do próprio negócio e muitas vezes você não tem funcionário, não tem uma equipe, é você mesmo quem faz a gestão financeira, administrativa, marketing e você que vai lá e executa, no meu caso a consultoria. A gente tem que fazer um pouco de cada coisa, outra característica é a mente aberta. Durante esses 10 anos de Alca treinamentos, a gente já direcionou a nossa empresa p várias coisas. Começamos dando treinamento para uma coisa e mudamos para outra. Fomos sentindo o mercado". (G.R.C. Associada à Lídera) 
$\mathrm{Na}$ visão da fundadora M.C., o empreendedor deve ter as demais características:

"Para mim um empreendedor é uma pessoa bem resolvida, a capacidade de perceber sua identidade e respeitar seus pontos fortes e seus pontos fracos. Segundo estabelecer uma visão, determinar até aonde eu quero ir. Ter uma boa comunicação, se comunicar com as pessoas e saber se fazer entender, e ter expectativas a serem atendidas, as pessoas saberem o que elas podem esperar de você e o que você também pode esperar de um sócio, de uma equipe, de um contador. " (M.C. Fundadora da Lídera)

A associada F.F.M. relaciona algumas características importantes que um empreendedor precisa ter e lista quais delas possui, reforçando assim as teorias abordadas no capítulo 2 deste estudo.

"Tem que ter coragem, não pode ter medo de errar, tem que ser flexível para mudar de opinião, observar as mudanças necessárias para seu negócio prosperar, precisa ter subsídios para tomar decisões imediatas para não ficar para trás no mercado. Precisa ser uma pessoa dedicada, comprometida, que não se preocupa tanto com o horário de trabalho e sim de estar presente sempre que possível. E dessas eu tenho a capacidade e empenho para tomar decisões, estar disponível, desenvolvimento e tentar sempre alavancar o negócio. A resiliência também é importante para o empreendedor" (F.F.M. Associada à Lidera)

\subsubsection{Percepção sobre Liderança pelas empreendedoras da Lídera}

Botelho (2008, p. 120) traz as contribuições significativas sobre gestão da liderança feminina, atribuindo a ela um modelo baseado no conhecimento humano. Neste contexto se valoriza características como flexibilidade, intuição, sensibilidade, capacidade de trabalhar em equipe e administrar as diversidades que são atributos mais direcionados ao sexo feminino.

Com relação a exercer um papel de líder e sobre o estilo de gestão a empreendedora R.M. comenta:

"Eu nunca tive um perfil de liderança como eu identifico nas outras pessoas. Sou muito mais voltada para a parte de identificação humanas, mas eu sempre trabalhei muito junto com as pessoas. Tenho um perfil mais colaborativo do que de liderança. Preciso desenvolver muito mais essa parte de liderança". (R.M. Associada à Lídera)

E ainda completa com relação a seu modo de influenciar pessoas e sobre a definição de metas a seus seguidores:

"Sou um tipo de líder mais cooperativo, que pega junto, vamos entender juntos o que precisa ser feiro, qual vai ser a parte de cada um, vou te ajudar na dificuldade que você tem. Eu não posso chegar de uma forma mais autoritária porque as pessoas precisam do meu serviço, estou ali para melhorar. Eu preciso fazer com que as pessoas se enxerguem no mesmo nível que eu e tenha muito esse sentido de colaboração, vamos fazer juntos". (R.M. Associada à Lídera) 
"É fundamental ter as responsabilidades bem definidas. Gosto de deixar bem definido o que cada pessoa é responsável, até onde vai o papel dela e o que ela também precisa receber do outro colega”. (R.M. Associada à Lídera)

Já a associada N.L.B. afirma que, "de certa forma me considero uma líder sim. Porque eu já vi em vários momentos a minha equipe replicar coisas do meu comportamento, e que eu acho que são importantes para gerenciar a equipe". Sobre o seu perfil de liderança ela ressalta:

"Eu acho que sou uma líder muito democrática, eu não me vejo como uma chefe, também não me vejo como colega das minhas funcionárias. Eu acho que por sermos uma empresa familiar, essa coisa da horizontalidade e não da verticalidade, está muito presente na minha empresa. A opinião das funcionárias é super bem-vinda, muitas vezes elas nos dão feedback de coisas que elas gostariam que nós melhorássemos enquanto líderes. Então eu acho que estamos sempre buscando o aprimoramento e desenvolver a equipe". (N.L.B. Associada à Lídera)

Baseado nas teorias dos tipos de liderança segundo (ROBBINS, 2011), a empreendedora e associada F.F.M, enfatiza que se junta a equipe para solucionar problemas:

"Eu entendo que eu não tenho uma liderança mais autoritária e sim mais "mãezona". Sou mais negociadora, de forma geral sempre que possível a gente tenta, mas obviamente muitas vezes não dá certo. Tu acabas tendo que partir mais para ordem e para o alinhamento, eu tento negociar, ponderar junto com a equipe envolvida nos trabalhos qual vai ser a melhor forma da gente solucionar o problema ou de atender o cliente". (F.F.M., Associada à Lídera)

Ao ser questionada sobre expressar confiança a seus liderados, M.B.D., afirma:

"Eu acredito que sim porque eu tenho exemplo, eu consigo tangibilizar essa pergunta que você faz, vendo o crescimento das pessoas, o quanto elas se desenvolvem, nas entregas diferenciadas que eles conseguem fazer, nas inovações que eles conseguem proporcionar. Então eu acho que tem isso sim". (M.B.D., Associada à Lídera)

\subsubsection{Rede de apoio e motivo por se associarem à Lídera}

No âmbito do apoio, segundo (HISRICH; PETERS; SHEPHERD, 2009), as mulheres costumam mencionar primeiramente seu cônjuge e amigos íntimos. Elas também contam com outras fontes de apoio e informação, como grupos profissionais femininos e associações comerciais.

No caso das empreendedoras da Lídera a teoria pode ser confirmada pois a maioria das respostas das mulheres entrevistadas responderam receber incentivo da família para criar e manter o empreendimento, como 
mostra o Gráfico 19 abaixo:

Gráfico 19: Rede de apoio empreendedora

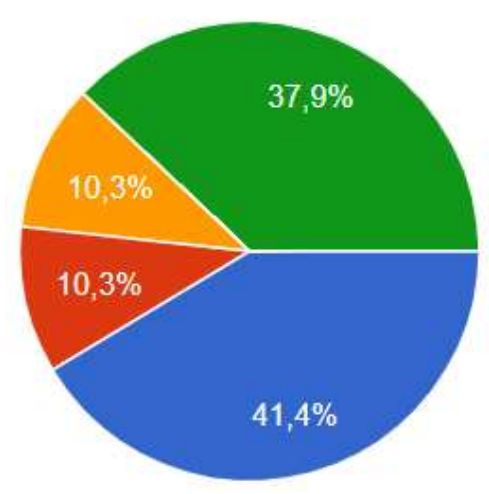

Possui incentivo da família para abrir/ cuidar do negócio

Sente-se sobrecarregada com as responsabilidades do negócio e da casa

Sente-se muito sobrecarregada

Possui sócios que ajudam a gerenciar o negócio

Fonte: Dados da pesquisa

No mercado através da plataforma de apoio Rede Mulher Empreendedora, as mulheres conseguem ter acesso a uma imensa gama de suporte necessário para a criação a estruturação do seu negócio como sites com conteúdo relevantes e de qualidade, eventos de networking, cursos, mentorias, parcerias com empresas que acreditam na causa do empreendedorismo feminino para levar oportunidades e facilidades para as mulheres; espaço publicitário em destaque no site, por meio de marketplace; indicações para fomentar o comércio entre pequenas mulheres donas de negócio. (SITE RME, 2018)

Nos gráficos abaixo (Gráficos 20 e 21), obtidos com dados do questionário, é possível identificar que tipo de apoio as associadas da Lídera julgam necessários e relevantes para seus negócios e quais os serviços que buscam dentro da associação. Logo, é possível observar a importância de uma rede de apoio a empreendimentos femininos, tendo em vista que as associadas selecionaram a maioria pelo menos seis temas. 


\section{Gráfico 20: Temas mais relevantes para as empreendedoras da Lídera e seus negócios}

\section{TEMAS MAIS RELEVANTES PARA AS EMPREENDEDORAS LÍDERA E SEUS NEGÓCIO}

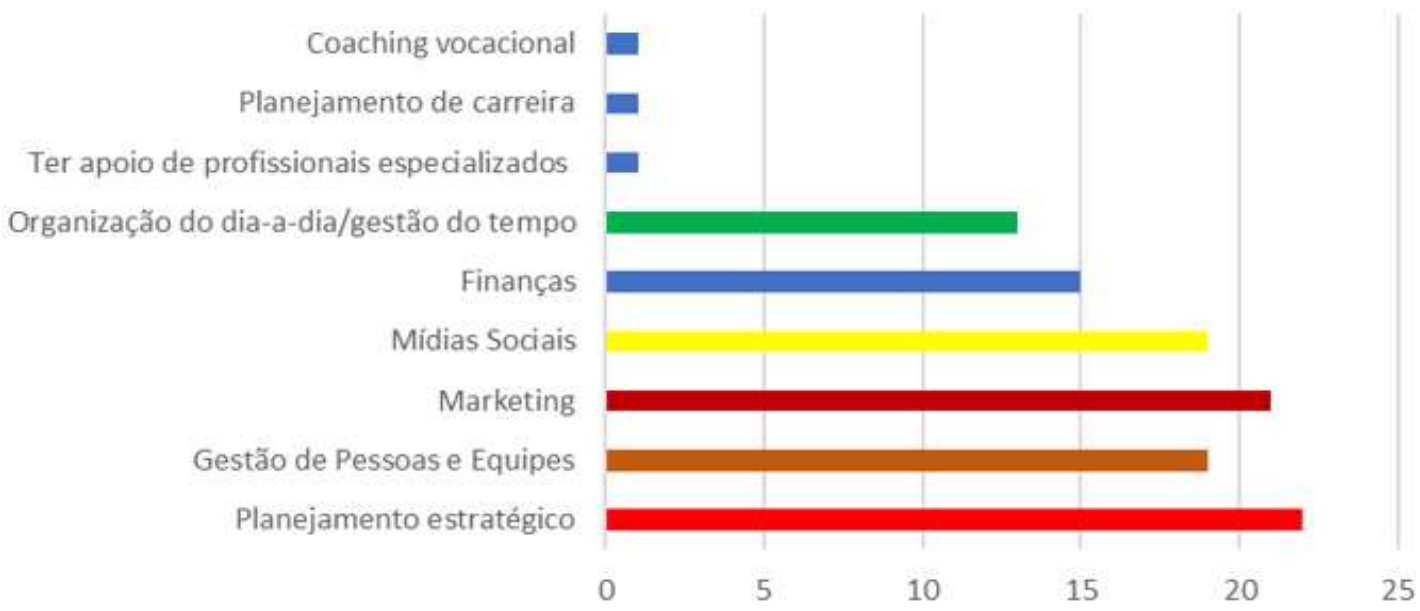

Fonte: Dados da pesquisa (2018)

\section{Gráfico 21 : Motivos pelas empreendedoras buscarem a lidera de acordo com os pilares da associação BUSCA PELA ASSOCIAÇÃO X PILARES DA LÍDERA}

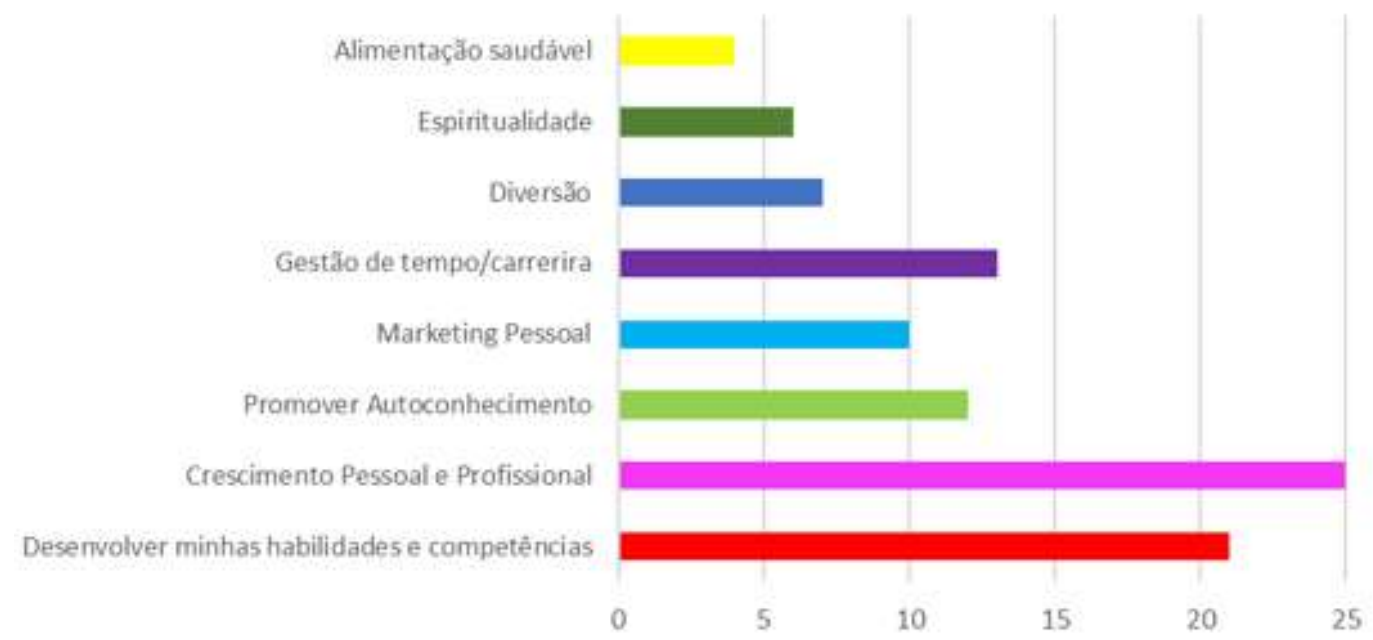

Fonte: Dados da pesquisa (2018)

Ao ser questionada sobre os motivos para se associar à Lídera, a empreendedora F.V. diz ter sido convidada pela fundadora da associação:

$\mathrm{Na}$ verdade, eu fui escolhida pela Lídera, e em março desse ano eu acabei aparecendo numa revista, uma reportagem sobre a minha trajetória numa revista regional aqui. E aí a M.C. acabou me ligando, eu a conheci de ouvir falar e ter amigos em comum, mas nunca tinha conversado com ela. Aí no dia que ela viu essa revista me perguntou se eu queria fazer parte da Lídera". (...) foi uma das coisas mais bacanas que aconteceu esse ano. Conheci um grupo de 
mulheres sensacionais e admiráveis através da Lídera. Me trouxe um networking fantástico. (F.V. Associada à Lidera)

A F.F.M. acredita que a Lídera é totalmente diferente de outros grupos que já participou:

"Fui convidada a participar de uma reunião inicial, e eu percebi que diferente de outros grupos de mulheres dos quais eu já tinha tentado participar, esse não era só um grupo a mais para bater fotos e fama, e sim era um grupo de mulheres que estavam decididas a fazer alguma diferença no mundo. Ou então que realmente se pensava em ações, em práticas que podem mudar a realidade aqui fora de outras mulheres. Na lidera eu consigo contribuir para que a gente possa ter ações e ter resultados reais". (F.F.M. Associada à Lídera)

A fundadora da Lídera M.C. identificou uma falha no suporte a mulheres que buscam empreender, gerando assim a vontade de criar a associação. Ela ainda completa dizendo que considera muito mais forte o alinhamento e apoio entre os homens:

Eu criei a Lídera, porque percebi que no momento de empreender tanto no CNPJ quando num CPF, existe um alinhamento e um apoio entre homens. Mas não existe esse alinhamento e apoio entre mulheres. Não existe essa questão de troca, de confiança, de um ambiente de aprendizagem, não existia isso. Foi então que eu senti a necessidade e criei a partir de 2015. Já tinha uma confraria que era $p$ reunir mulheres e eu vi que tinha uma oportunidade de reunir mulheres, não com foco de tomar um espumante e entretenimento, mas também para discutir sobre os desafios do empreendedor empreender enquanto mulher. (M.C. Fundadora da Lídera)

A empresária M.B.D comenta numa visão no âmbito regional sobre as necessidades de uma estruturação de uma rede de apoio e também aponto que a muitos grupos possuem forte atuação masculina:

"Foi uma iniciativa de um grupo de mulheres que começaram a se reunir para outras questões, e isso teve adesão. Já se falava porque não montar uma associação para aglutinar todas essas pessoas interessadas a conversar sobre negócios e tal. Então, quando eu participo, eu sou diretora, inclusive, da Lidera, então somos o grupo fundador, que iniciou com conversas e a gente viu espaço. Porque na cidade, a maioria das associações, do que tem, a maioria é dominado por homens, associação comercial, CDE, então tem uma forte atuação masculina. E a gente achou que tem muitas lideranças femininas, muito conhecimento, muitas pessoas com destaque e não tem muito espaço para poder socializar isso, falar sobre isso. Então a gente resolveu fundar a Lidera. Para mim, a lidera me representa enquanto mulher, enquanto espaço para discutir e também para você apresentar os teus negócios, networking, fazer todo esse relacionamento". (M.B.D. Fundadora da Lídera) 


\section{Conclusões e recomendações para novos estudos}

O presente estudo teve como principal objetivo identificar o perfil empreendedor feminino e suas características, em específico das mulheres que se associaram à Lídera.

Este trabalho de conclusão de curso inicialmente tratou da revisão da literatura, abordando temas como empreendedorismo feminino, características do perfil empreendedor feminino e liderança feminina, utilizando como principais autores: Jonathan (2011), Gomes e Santana (2009), Hisrich; Peter; Shepherd, (2009), Dornelas (2003), (1999) apud Pñaloza; Diógnes; Souza, (2008), Machado (2002), Botelho (2008), Frankel (2007), entre outros.

O tópico empreendedorismo apresentou o conceito de empreendedorismo, o cenário atual do empreendedorismo no Brasil e no Rio Grande do Sul, razões para empreender, a importância da elaboração de um plano de negócio e as características de um empreendedor de sucesso.

O tópico empreendedorismo feminino abordou o conceito de empreendedorismo feminino, motivos que levaram as mulheres a empreender, a participação da mulher na renda familiar, a ponte entre trabalho e família, os desafios enfrentados pelas mulheres ao criar um negócio, as características atribuídas ao perfil empreendedor feminino e a relevância de uma rede de apoio a mulheres empreendedoras. Por fim, o último tópico abordou os conceitos da liderança feminina, o estilo feminino de liderar nos empreendimentos criados e as características da liderança exercida por mulheres.

Uma vez apresentado o método e o procedimento de coleta e análise dos dados do estudo, seguiu-se com a apresentação da organização objeto do estudo de caso: a Lídera.

Foi identificado por meio do estudo as características mais recorrentes do perfil das empreendedoras da Lídera, são elas: assumir riscos, foco, identificar uma oportunidade de mercado e determinação.

Através do estudo foi possível destacar a compreensão sobre liderança das empreendedoras associadas na visão dos seus negócios. Sendo assim, as mulheres pertencentes à Lídera, em sua maioria, se consideram como líderes carismáticas, humanas, buscam definir muito bem os papéis e funções 
de seus liderados, e se juntam as eles a fim de solucionar problemas e entender suas necessidades.

Os principais desafios enfrentados pelas empreendedoras da Lídera para a criação e desenvolvimento dos negócios, foram: a comparação entre gêneros pelo trabalho executado, planejamento e investimento financeiro e a burocratização.

Conclui-se que dentre os motivos que levaram as empreendedoras a buscar a Lídera, alguns se destacaram mais como: a necessidade de um planejamento estratégico, suporte ao marketing do negócios e mídias sóciais, para crescimento pessoal e profissional, desenvolver suas habilidades e competências, e para aprender a ter uma melhor gestão do tempo e carreira.

Vale ressaltar que o estudo diagnosticou que as empreendedoras Líderas aumentaram a sua participação na renda familiar após a abertura dos seus empreendimentos.

Diante do exposto anteriormente, pode-se concluir que a Lídera enquanto associação, mesmo tendo pouco tempo de existência, tem um papel fundamental de suporte as suas associadas para enfrentar desafios relatados na pesquisa.

Como sugestão de continuidade para este estudo, propõe-se que sejam realizadas entrevistas com todas as associadas da Lídera de forma a criar um panorama completo das associadas., permitindo assim que a Associação crie um plano de expansão das suas atividades.

Além disso, o estudo pode ser continuado no sentido de criar um modelo de criação de "confrarias" como a Lídera alcançando uma abrangência regional e nacional maior por meio do uso da metodologia de apoio a mulheres empreendedoras.

Entende-se que outras redes de apoio para mulheres possam ser estudadas comparativamente no sentido de valorizar as melhores práticas realizadas por essas iniciativas. 


\section{Referências Bibliográficas}

AGÊNCIA BRASIL. Elas lideram: Mulheres ultrapassam os homens na criação de novos negócios no País. 2017. Disponível em:https://www.huffpostbrasil.com/2017/08/06/mulheres-lideram-criacao-denovos-negocios-no-pais a 23067321/. Acesso: 10 out.2018.

AGENCIA SEBRAE DE NOTICAS. Mulheres empreendem mais que os homens. Disponível em: http://www.agenciasebrae.com.br/sites/asn/uf/NA/mulheres-empreendemmais-que-os-homens,00705bd2fb7f1610VgnVCM1000004c00210aRCRD. Acesso: 01 nov.2018.

BOTELHO, Louise de Lira Roedel. Ascensão profissional de Executivas em empresas baseadas no conhecimento. 2008. 161f. Trabalho de conclusão de curso (dissertação)- Universidade Federal de Santa Catarina, Programa de Pós-Graduação em Engenharia e Gestão do Conhecimento, Florianópolis (SC), 2008. Disponível em: Acesso em 20 out. 2018.

BRITISH COUNCIL. O papel dos negócios sociais no apoio ao empoderamento feminine no Brasi. Disponível em: https://www.britishcouncil.org.br/sites/default/files/negocios-sociaisempoderamento-feminino-brasil.pdf. Acesso: 03 nov.2018.

BRITO,F.;WEVER,L.Empreendedores Brasileiros II: a experiência e as lições de quem faz acontecer.São Paulo: Negócio Editora, 2004.

BRITTO, Francisco e WEVER, Luiz. Empreendedores brasileiros: vivendo e aprendendo com grandes nomes. 2.ed. Rio de Janeiro : Campus, 2003. p. 1724.

BRYMAN, Alan. Liderança nas Organizações. In: CLEGG, Stewart R.; HARDY, Cynthia; NORD, Walter R. (org.). Handbook de Estudos Organizacionais: ação e análise organizacionais. vl. 03. p. 257-281. Editora Atlas. São Paulo, 2004.

BUTTNER, E. H., \& MOORE, D. P. (1997, January). Women's organizational exodus to entrepreneurship: self-reported motivations and correlates with success. Journal of Small Business Management, 35, 34-46.

CARLAND, J., CARLAND, J., CARD, R. (2005). The multi-facets of female entrepreneurship: their dreams and their realities. In Proceedings of the World Conference of the International Council for Small Business, Washington, DC.

CARREIRA, Suely et al. Empreendedorismo feminino: um estudo fenomenológico. Navus-Revista de Gestão e Tecnologia, v. 5, n. 2, p. 06-13, 2015.

CHIAVENATO, Idalberto. Introdução à teoria geral da administração: uma visão abrangente da moderna administração das organizações. Vol. 7 edição revisada e atualizada. Rio de Janeiro: Elsevier, 2003.

CHIAVENATO, Idelbrando. Gestão de Pessoas: o novo papel dos Recursos Humanos nas Organizações. $6^{a}$ tiragem. Rio de Janeiro: Campus, 1999. 
CIPOLETA, S. CLARICE. Empreendedorismo e Liderança: um estudo sobre os conhecimentos, habilidades e atitudes necessários ao líder empreendedor. 2018. Disponível em: https://www.portaleducacao.com.br/conteudo/artigos/conteudo/empreendedo rismo/19111. Acesso em: 30 out.2018.

CIROLINI, Vicente; NORO, Greice de Bem. A participação da mulher na gestão das cooperativas: um estudo realizado na Cotrisel. Disciplinarum Scientia. Série: Ciências Sociais Aplicadas, S. Maria, v. 4, n. 1, p. 29-43, 2008.

CONSTANTINO, TOR. 3 Ways This Female Entrepreneur Succeeds on Her Own Terms. 2015.2 Disponível em: https://www.entrepreneur.com/article/253761. Access: 06 out. 2018.

DEGEN, J. R. O Empreendedor: empreender como opção de carreira. São Paulo: Pearson Prentice Hall, 2009.

DEGEN, Ronald. O Empreendedor: Fundamentos da iniciativa empresarial. São Paulo: McGraw Hill, 1989

DOLABELA, Fernando. Oficina do Empreendedor: a metodologia de ensino que ajuda a transformar conhecimento em riqueza: $1^{\text {a }}$ ed. São Paulo: Editora Cultura, 1999.

DORNELAS, J. Empreendedorismo Corporativo - Como ser empreendedor, inovar e se diferenciar na sua empresa. Rio de Janeiro: Elsevier, 2008.

DORNELAS, J. Empreendedorismo para visionários: desenvolvendo negócios inovadores para um mundo em transformação. Rio de Janeiro: Empreende / LTC, 2014.

DORNELAS, J. Empreendedorismo: transformando idéias em negócios. Rio de Janeiro: Elsevier, 2005.

DORNELAS, José Carlos de Assis. Empreendedorismo Corporativo: como ser empreendedor, inovar e se diferenciar em organizações estabelecidas: $2^{a}$ ed. Rio de Janeiro: Editora Elsevier, 2003.

DORNELAS, José. Empreendedorismo: Transformando ideias em negócios. 4. ed. Rio de Janeiro: Elsevier, 2012.

DRUCKER, Peter Ferdinand. Inovação e espírito empreendedor. São Paulo: Pioneira, 1986.

EAGLY, A., \& CARLI, L. (2003) The female leadership advantage: An evalution of the evidence. The Leadership Quarterly, n¹4, pp. 807 - 834. Disponível em: http://academics.wellesley.edu/Psychology/Psych/Faculty/Carli/FemaleLeade rshipAdvantage.pdf. Acesso em: 04 out.2018.

EAGLY, Alice. H. Women as leaders. In: Leadership Style Versus Leaders' Values and Attitudes. In: Gender \& Work: challenging conventional wisdom. Cambridge, MA: Harvard Business School Press, 2013.

FILION, Louis; DOLABELA, Fernando. Boa Ideia! E agora: plano de negocio, 


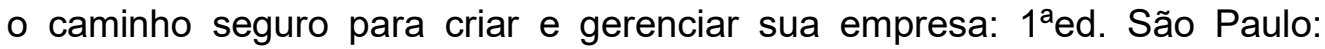
Editora Cultura, 2000.

FRANKEL, P. LOUIS. 2007.Mulheres Lideram Melhor Que Homens.

GIL, A. C. Métodos e técnicas de pesquisa social. 5.ed. São Paulo: Atlas, 1999.

GOMES, A. F. O perfil empreendedor de mulheres que conduzem seu próprio negócio: um estudo na cidade de vitória da Conquista, Bahia. Revista Alcance - UNIVALI - v. 11, n.2 p. 207 - 226, maio/ago, 2004.

GOMES, A. F.; SANTANA, W. G. P. As Habilidades de Relacionamento Interpessoal de Mulheres que Trabalham por Conta Própria: o Caso de Vitória da Conquista-BA. VII SEMEAD - Seminário de Administração FEA/USP, Anais, 2004.

GOMES, A.F; SANTANA, P.G.W.; SILVA, M.J. .Mulheres Empreendedoras: Desafios e Competências. 2009. Disponível em: <http://www.cyta.com.ar/ta0406/v4n6a1.htm>. Acesso em: 25 out. 2018.

GOMES, D. T; GUERRA, P. V. \& VIEIRA, B. N. (2011). "O Desafio do Empreendedorismo Feminino". In: Anais do Encontro da ANPAD. 35. Rio de Janeiro.

GOMES, F. A., SANTANA, P. G., \& SILVA, M. J. (2005). Mulheres empreendedoras desafios e competências. Técnica Administrativa. Buenos Aires, vol. 4, n. 24, out./dez. 2005.

GUPTA, V. K. et al. Entrepreneurship and stereotypes: are entrepreneurs from Mars or from Venus? Academy of Management Best Conference Paper, 2005.

HISRICH, R. D.; PETERS, M. P., SHEPHERD, D. A. Empreendedorismo. 7 ed. Porto Alegre: Bookman, 2009.

HISRICH, Robert; PETERS, Michael. Empreendedorismo: $5^{\text {a }}$ ed. Porto Alegre: Editora Bookman, 2004.

HUGO, MATHEUS. 2015. Treinamento e desenvolvimento de pessoas. Disponível em: https://www.rhportal.com.br/artigos-rh/treinamento-edesenvolvimento-de-pessoas-2/. Acesso: 23 out.2018.

INOVATIVAS BRASIL. 11 mulheres e um segredo! Os desafios do empreendedorismo feminino. 2017. Disponível em: https://www.inovativabrasil.com.br/11-mulheres-e-um-segredo/ . Acesso: 29 set.2018.

JONATHAN E. G. (2001) "Mulheres Empreendedoras: Quebrando Alguns Tabus." Anais CDROM (n.69), III Encontro Nacional de Empreendedorismo (ENENPRE), UFFC,Florianópolis, Santa Catarina, 5 e 6 de dezembro.

JONATHAN, E. G. (2003). Empreendedorismo feminino no setor tecnológico brasileiro: dificuldades e tendências. Em $3^{\circ}$ EGEPE-Encontro de Empreendedorismo e Gestão de Pequenas Empresas, Anais do Encontro. Brasília: UEM/UEL/UnB, 41- 53. 
JONATHAN, Eva G. Mulheres empreendedoras: o desafio da escolha do empreendedorismo e o exercício do poder. Psicologia Clínica, v. 23, n. 1, p. 65-85, 2011.

JONATHAN, Eva Gertrudes. Empreendedorismo feminino no setor tecnológico brasileiro: dificuldades e tendências. Encontro de Gestão Estratégica de Pequenas Empresas, n. 3, 2003.

JONATHAN, Eva Gertrudes. Mulheres empreendedoras: medos, conquistas e qualidade de vida. Psicologia em Estudo, Maringá, v. 10, n. 3, p. 373-382, set/dez, 2005.

KOTLER, Philip. Marketing 3.0 As forças que estão definindo o novo marketing. Rio de Janeiro: Elsevier, 2010.

LACOMBE, Francisco José Masset. Recursos Humanos Princípios e Tendências. Ed. Saraiva, $2^{a}$ edição, 2011.

Lectures on Schumpeterian Economics, New York: Springer-Verlag,2005.

LÍDERA<https://www.lidera.pro.br/> Acesso em: 03/11/2018.

MACEDO, M.M. GEM - Empreendedorismo no Brasil. Curitiba, IBQP, 2013.

MACHADO, H. V. (2002). Identidade empreendedora de mulheres no Paraná. (Tese de Doutorado). Programa de Pós-Graduação em Engenharia de Produção. Universidade Federal de Santa Catarina.

MACHADO, H. V.; ST CYR, L.; MIONE. A.; ALVES, M. C. M. O processo de criação de empresas por mulheres. RAE Eletrônica, v. 2, n. 2, p. 1-22, 2003.

MACHADO, Hilka Vier. Tendências do comportamento gerencial da mulher empreendedora. Encontro Nacional dos Programas de Pós-Graduação em Administração, v. 23, 1999.

MARCONI, M. A; LAKATOS, E. M. Técnicas de pesquisa: planejamento e execução de pesquisas, amostragens e técnicas de pesquisas, elaboração e interpretação de dados. 3.ed. São Paulo: Atlas, 1996.

MIRANA, ELISABETE. Mulheres no empreendedorismo. 2018. Disponível em: https://www.mulheresempreendedoras.net.br/mulheres-noempreendedorismo/. Acesso: 06 out.2018.

MORI, FLAVIO. Empreender Identificando, avaliando e planejando um novo negócio. Florianópolis: Escola de Negócios Editora, 1998.

MUNHOZ, G. de S. Quais as contribuições que o estilo feminino de liderança traz para as organizações empreendedoras? In: Encontro Nacional de Empreendedorismo. Maringá, 2000.

NORTHOUSE, P. Leadership: Theory and Practice. $5^{\mathrm{a}}$ Ed. Thousand Oaks, CA: Sage Publications, 2007

SEBRAE.Os Donos de Negócio no Brasil: análise por sexo (2001 a 2014). Outubro (2016).

Disponível

em: 
http://www.sebrae.com.br/sites/PortalSebrae/estudos pesquisas/os-donosdo-negocio-nobrasildetalhe34,0a8f59d84cda5410VgnVCM2000003c74010aRCRD. Acesso: 18 out. 2018 .

PEÑALOZA, V.; DIÓGENES, C.G.; SOUZA, S. J. A. Escolha professional no curso de aministração: Tendencias empreendedoras e genero. Revista de adinistração Mackenzie, v. 9, n. 8, p. 151-167, nov./dez. 2008.

PEGN - Pequenas Empresas e Grandes Negócios. Conheça o perfil das mulheres que empreendem no Brasil. 2017. Disponível em: http://g1.globo.com/economia/pme/pequenas-empresas-grandesnegocios/noticia/2017/12/conheca-o-perfil-das-mulheres-que-empreendemno-brasil.html. Acesso: 03 nov.2018.

PERIARD, GUSTAVO. 2010. Empretec - o que é e como funcionada. Disponível em: http://www.sobreadministracao.com/empretec-o-que-e-ecomo-funciona/. Acesso: 03 nov.2018.

PORTAL FACSENAC. Um estudo do comportamento de mulheres empreendedoras no distrito federal. (2012). Disponível em: http://facsenac.edu.br/portal/images/documentos/revista gecom/edicao 1/3a rtigo-1ed.pdf. Acessado: 21 set.2018.

PORTER, M.; KRAMER, M. Creating shared value. Harvard Business Review, Boston, Jan .- Feb. 2011.

RAPOSO, Kariny C. de Souza; ASTONI, Sílvia A. Ferreira. A mulher em dois tempos: a construção do discurso feminino nas revistas dos anos 50 e na atualidade. Cadernos Camilliani. Revista do Centro Universitário São Camilo, ES, v. 8, n. 2, p. 36-37, 2007.

ROBBINS, Setphen Paul. Administração: mudanças e perspectivas. Tradução Cid Knipel Moreiral. São Paulo: Saraiva, 2000.

ROBBINS, Stephen. SOBRAL, Filipe. Comportamento Organizacional - teoria e prática no contexto brasileiro. 14ª . Edição SP. Editora Pearson, 2011.

ROBINS, S. Fundamentos do Comportamento Organizacional. 8a edição. Pearson, 2009.

SALIM, C.; NASAJON, C. V.; SALIM, H.; MARIANO, S. Administração Empreendedora: teoria e prática usando estudos de casos. 1.ed. Rio de Janeiro: Campus, 2004.

SCHUMPETER, J. A. The Theory Of Economic Development Cambrigde, Mass.; Harvard University. 1949.

SCHUMPETER, Joseph A (1982). Teoria do desenvolvimento econômico: uma investigação sobre lucros, capital, crédito, juro e o ciclo econômico. São Paulo: Abril Cultural.

SCHUMPETER, Joseph Alois. Capitalism, Socialism and Democracy. Nova York: Harper and Brothers, 1942. 
SEBRAE PIAUÍ. Atitude empreendedora - EMPRETEC. 2018. Disponível em: http://www.sebrae.com.br/sites/PortalSebrae/ufs/pi/sebraeaz/empretec,32ab4 76a91983610VgnVCM1000004c00210aRCRD. Acesso: 03 nov.2018.

SEBRAE. Como agir de maneira empreendedora. MEI, SOU DONO DO MEU NEGÓICO. Brasília 2018. Disponível em: http://www.sebrae.com.br/Sebrae/Portal\%20Sebrae/UFs/BA/Anexos/Como\% 20agir\%20de\%20maneira\%20empreendedora.pdf. Acesso: 08 out.2018.

SEBRAE. Empreendedorismo no Rio Grande do Sul. Relatório Executivo. 2016. Disponível em: http://datasebrae.com.br/wpcontent/uploads/2018/07/Relat\%C3\%B3rio-executivo-GEM-RS.pdfv. Acesso: 07 set.2018.

SEBRAE. Global Entrepreneurship Monitor. Pesquisa GEM 2017. Disponível em: https://m.sebrae.com.br/sites/PortalSebrae/estudos pesquisas/pesquisagem-empreendedorismo-no-brasil-e-nomundodestaque9,5ed713074c0a3410VgnVCM1000003b74010aRCRD. Acesso em: 29 set. 2018 .

SILVEIRA, A., GOUVEIA, A. B. C. T., \& HOELTGEBAUM, M. (2007). Empreendedorismo feminino: Características, considerações e entendimentos de mulheres gerentes de Micro e Pequenas Empresas de Santa Catarina, Brasil. In: Anais do X Seminário em Administração, 2007. São Paulo. Anais do $X$ SIMPOI, São Paulo.

STODGILL, R. M. Handbook of Leadership: A Survey of Theory and Research. New York: Free Press, 1974.

STROBINO, M. R. C. \& TEIXEIRA, R. M. (2014). "Empreendedorismo Feminino e o Conflito Trabalho-Família: Estudo de Multicasos no Setor da Construção Civil da Cidade de Curitiba". Revista Administração, USP, São Paulo, 49(1):1-18. jan./fev./mar.

SWOBODA, P. Schumpeter's Entrepreneur in Modern Economic Theory. Lectures on Schumpeterian Economics, New York: Springer-Verlag,2005.

TEIXEIRA, Elizabeth. As Três metodologias: acadêmica, da ciência e da pesquisa. Petropolis, RJ: Vozes, 2005.

TEIXEIRA, S. (2005). Gestão das organizações (2a ed.). Lisboa: McGraw Hill.

TIEDGE, L. B. (2004). Processes of change in work/home incompatibilities: Employed mothers 1986-1999. Journal of Social Issues. Disponível em: https://spssi.onlinelibrary.wiley.com/doi/pdf/10.1111/j.0022-

4537.2004.00386.x. Acesso em: 12 out.2018.

WEISE, ANGELICA. Entrevista com idealizadores da ONG Rede de Mulheres Empreendedoras. 2018. Disponível em: https://www.eusemfronteiras.com.br/entrevista-com-idealizadores-da-ongrede-de-mulheres-empreendedoras/. Acesso: 23 out.2018.

WIESEL, GILBERTO. 2013. Características das Mulheres Empreendedoras. Disponível em: http://www.empregoerenda.com.br/editorias/artigos/1119- 
mulheres-empreendedoras. Acesso: 30 set.2018.

WIESEL, GILBERTO. Mulheres Empreendedoras. 2010. Disponível em: http://www.portaldomarketing.com.br/Artigos2/Mulheres empreendedoras.ht m. Acesso: 02 nov.2018.

WU, A. (2011) Do Startup Accelerators Delvier Value? The Economics of Creating Companies, MIT Entrepreneurship Review, August 14th \& $22^{\text {nd }}$.

YIN, Robert K. Estudo de caso: planejamento e métodos. 4. ed. Porto Alegre: Bookman, 2010.

YUKL, Gary A. Leadership in organizations. Nova Jersey: Prentice Hall, 1998. ZIKMUND, William G.; BABIN, Barry J. Princípios da pesquisa de marketing. 4. ed.São Paulo: Cengage Learning, 2011. 


\section{Anexo I - Formulário}

\section{SEÇÃO 1. IDENTIFICAÇÃO DAS EMPREENDEDORAS LÍDERA}

Obrigada por sua adesão na Lidera - Associação de Mulheres Empreendedoras

Visando construir uma base estatística, validar e qualificar as informações que já possuimos e, levantar o perfil de todas as nossas associadas, convidamos você para preencher nossa pesquisa

Essas informações são fundamentais para conhecermos o seu posicionamento no mercado e seu perfil de empreendedora para propormos soluções e oportunidades convergentes com suas necessidades e expectativas.

*Obrigatório

1. Endereço de e-mail *

2. Nome completo: *

3. Documentos de identificação (CPF) *

4. Data de nascimento: *

Exemplo: 15 de dezembro de 2012

5. Endereço Residencial - [RUA] *

6. Número: *

7. Complemento:

8. Bairro: *

9. CEP: *

10. Cidade: * 
11. Estado:

12. Telefone (celular):

13. E-mail: *

14. Formação: *

Marcar apenas uma oval

Ensino Fundamental

Ensino Médio

Graduação

Especialização e/ou mestrado e/ou doutorado

15. Profissão: *

16. Local de trabalho: *

17. Estado civil: *

Marcar apenas uma oval.
Solteira
Casada
Divorciada
Separada
União estável
Viúva

18. Tem filhos? Quantos?

\section{SEÇÃO 2. INFORMAÇÕES GERAIS DO SEU LADO}

\section{EMPREENDEDORA}

Esta seção busca identificar questóes essenciais para mapearmos o estágio e os desafios das nossas empreendedoras Lídera.

19. Você possui um NEGÓCIO próprio?

Marcar apenas uma oval.
$\operatorname{Sim}$
Não 
20. Se não possui, diga se vocề é intraempreendedora em algum lugar."

21. Se possui, è seu primeiro NEGOCCIO?* Marcar apenas uma oval

Sim

Nä่อ

22. Se não é o seu primeiro negócio, diga quantos e quais foram.

23. Realizou algum planejamento para a abertura do negócio? Marcar apenas uma oval.

Sim, eu mesma elaborei um plano de negócio

Sim, através de um consultor

Apenas um planejamento mental

Nä̀

Outro:

24. Em que FASE seu negócio se encontra? * Marcar apenas uma oval.

Está em fase de planejamento, ainda é só uma ideia!

Está em fase de implantaçäo, está saindo do pape!!

Já está implantado e rodando

Está na fase ou vai ou racha!

Meu negócio está consolidado

25. Quanto TEMPO tem seu NEGÓCIO? * Marcar apenas uma oval.
Está em fase de planejamento
Existe há menos de 1 ano
Entre 1 e 3 anos
Entre 4 e 6 anos
Entre 7 e 10 anos
Mais de 11 anos 
26. Qual o SETOR que se enquadra seu negócio? =

Marcar apenas uma oval.
Indústria
Comércio
Serviços
Consultorias e treinamentos
Alimentos
Outro:

27. Quem administra seu atual negócio? *

28. Quais foram as RAZÕES PARA vocé EMPREENDER? *

Marque todas que se aplicam.
Deseja trabalhar com o que gosta
A flexibilidade de horánio
Possibilidade de trabaihar de casa
- Estar em busca de uma renda melhor
- Ter mais tempo para filhos e familia
$\square$ Identificou uma oportunidade de mercado
$\square$ Realização de um sonho

Q Outro:

29. Qual recurso econòmico utilizado para iniciar o negócio? " Marcar apenas uma oval.

Recurso da família

Recurso próprio

Poupança

Recurso proveniente de Rescisäo

Recurso de investidores

Outro:

30. Como está sua REDE DE APOIO como empreendedora? * Marcar apenas uma oval.

Dossui incentivo da família para abrir/cuidar do negócio

Sente-se sobrecarregada com as responsabilidades do negócio e da casa

Sente-se muito sobrecarregada

Possui sócios que ajudam a gerenciar o negócio 
31. Quais temas são RELEVANTES PARA vocè EMPREENDEDORA e para o seu negócio? * Marque todas que se aplicam.

$\square$ Marketing
$\square$ Midias sociais
$\square$ Finanças
$\square$ Organização do dia-dia/gestão do tempo
$\square$ Planejamento estratégico
$\square$ Gestäo de pessoas e equipes
$\square$ Outro:

32. Quais temas você julga serem RELEVANTES PARA EMPREENDEDORAS em fase de PLANEJAMENTO?*

Marque todas que se aplicam.

Marketing e comunicaçäo

Midias Sociais

Abertura/formalizaçào de empresas

1] Planejamento estratégico

Formação de preço

Organização do dia-dia/gestão do tempo

Outro:

33. De acordo com os 3 pilares da ASSOCIAÇÄO - Empreendedorismo e Negócios, Bem-estar e Social quais dessas atividades vocẻ está buscando na Lídera? *

Marque todas que se aplicam.

$\square$ Desenvolver minhas habilidades e competências
$\square$ Promover autoconhecimento
$\square$ Espiritualidade
$\square$ Alimentação saudável
$\square$ Gestäo do tempo/carreira
$\square$ Diversä。
$\square$ Marketing Pessoal
$\square$ Crescimento Pessoal e Profissional
$\square$ Outro:

34. Se você marcou OUTROS na questão anterior, descreva por favor.

SEÇÃO 3. FALANDO AGORA DO SEU NEGÓCIO

Preencha essa seção apenas se vocẻ possuir negócio próprio. 
35. Nome Fantasia:

36. CNPJ

37. Endereço e número:

38. Bairro:

39. Cidade:

40. CEP:

41. Telefone - Celular/Whatsapp:

42. E-mail:

43. Porte da empresa (de acordo com a Lei Geral das MPEs e BNDS):

Mancar apenas uma oval.

MEl - Micro Empreendedor Individual

Microempresa - Faturamento anual igual ou inferior a R\$ 380 mil

Pequeno Porte - Faturamento anual entre R\$ 360 , mil a RS 4,8 milhŏes

Média - Faturamento anual maior que RS 4,8 milhöes e menor ou igual a RS 300 milhões

Grande - Faturamento maior que R\$ 300 milhóes

44. $\mathbf{N}^{*}$ de Funcionários:

45. Data da Fundaçäo: 
46. Quanto sobra ANUALMENTE para você do seu negócio?

Marcar apenas uma oval.

Não faço ideia

Entre R\$12 mil à R\$ 35 mil (média entre 1 a 3 salários mès)

Mais que R\$ 35 mil e menos ou igual a R\$ 58 mil (média acima de 3 e até 5 salários mès)

Mais que RS 58 mil e menos ou igual a R\$ 115 mil (média acima de 5 e até 10 salários més)

Mais que RS 115 mil (média acima de 10 salários mês)

47. Ramo da empresa:

48. Produto:

\section{Sócios, proprietários ou administradores}

49. Nome do sócio 1 :

50. Cargo que exerce:

51. Nome do sócio 2:

52. Cargo que exerce:

53. Se vocè pudesse DESCREVER O SEU NEGÓGIO em poucas palavras o que vocè diria?

54. Para FINALIZAR.... qual a sua expectativa com a Lídera? 


\section{Anexo II - Roteiro de Entrevistas}

\section{Roteiro de entrevista - Empreendedoras Lídera}

Temas: empreendedorismo, características empreendedoras, desafios ao empreender, participação das empreendedoras na renda familiar, motivo de escolher a associação e compreensäo de liderança das empreendedoras associadas.

1. Quais as dificuldades que você enfrentou para abrir o negócio?

2. Quais as dificuldades que você enfrentou para abrir o negócio?

3. Vocẻ possui algum outro trabalho? Se sim, qual? Se não, onde trabalhava antes de abrir seu próprio negócio?

4. Por que escolheu a Lidera?

5. Que tipo de apoio sua família/companheiro te dá no seu dia a dia?

6. Você acredita que ter o próprio negócio é uma forma de ascensäo profissional $e$ social?

7. Depois que abriu o seu negócio, qual é a sua participação na renda da sua família? Aumentou ou diminuiu?

8. Quais atitudes na sua opinião influenciam diretamente o sucesso do empreendedor?

9. Você acredita que para empreender é preciso ser criativa e inovadora? 
10. Qual o perfil dos empreendedores de sucesso na sua opinião? E quais dessas características você tem?

11. Você se considera uma líder?

12. Vocé acredita que influencia outras mulheres através do seu trabalho? O que leva a crer isso?

13. Vocẻ acredita que gerencia/coordena sua equipe da melhor maneira?

14. Que tipo de lider você se considera?

15. Você expressa confiança aos seus liderados em relação a atingir expectativas de alto desempenho e satisfação?

16. Você acredita que inspira seus seguidores a transcender seus próprios interesses para o bem do seu negócio?

17. Você estabelece metas para seus liderados? Define muito bem os papeis e as tarefas de cada um?

18. Você possui alguma dificuldade ao liderar sua equipe de trabalho?

19. Você realizou algum tipo de treinamento com sua equipe de trabalho? 